\title{
'Salvation' (Soteria) and Ancient Mystery Cults
}

In the late nineteenth and early twentieth centuries it was sometimes said that ancient mystery cults were 'religions of salvation' (Erlösungsreligionen). According to these scholars, the gods of mysteries were often called Soter and the main purpose of initiation was to attain soteria in a spiritual and eschatological sense. Such ideas were adopted in, among others, Richard Reitzenstein's Die hellenistiscen Mysterienreligionen (1910) and Paulys Real-Encyclopädie der classischen Alterthumswissenschaft:

'Soter is perceived as the bringer of soteria, and soteria, salus, varies between the preservation of earthly life and the "granting of a new, higher, (life)" that is closer to god, more moral and superior to death, into which one is "reborn" through a mysterion. Soter as saving $(\sigma \omega \zeta \omega v)$ in an entirely concrete sense becomes a helper in attaining soteria, a "salvation" in a religiously more abstract, unearthly and more spiritual sense'.

Underlying these views is the tendency, common in early scholarship, to identify antiquity's influence on early Christianity. ${ }^{2}$ Ancient mystery cults, it is said, were very much concerned with the destiny of the soul and the afterlife, and therefore already expressed the very same spiritual concern for individual salvation that was later expressed in Christianity. This salvation concerned not only this life but also life after death, and could be attained by sharing the experience of the 'saviour god', especially Dionysus, Attis and Osiris, who had himself died but risen again. These ideas have widely influenced early interpretations of ancient mysteries. ${ }^{3}$ Thus Percy Gardner, Professor of Archaeology at Cambridge and Oxford, who was interested in Biblical studies, wrote:

'The deity of the [Hellenistic] society was a $\theta \varepsilon \dot{\delta} \varsigma \sigma \omega \tau \eta \dot{\eta} \rho$; and the society sought through fellowship with him to reach a state of $\sigma \omega \tau \eta \rho i \alpha$, safety or salvation, a salvation belonging alike to the present life and that beyond the grave... It was the deities of the Mysteries who were in an emphatic sense the saviours of those who trusted in them, and they saved by allowing the votary to have a share in their lives'. ${ }^{4}$

\footnotetext{
* I am most grateful to Professor Robert Parker for commenting on an earlier version of this article. I thank also the referees of $A R G$ for helpful suggestions.

${ }^{1}$ F. Dornseiff (1929), RE III.A, s.v. Soter, 1216-17: ' $\Sigma$. wird empfunden als Bringer einer $\sigma \omega \tau \eta \rho i \alpha$, und $\sigma \omega \tau \eta \rho i \alpha$, salus schwankt zwischen Erhaltung des irdischen Lebens und, Verleihung eines neuen, höheren', gottnäheren, sittlicheren, todüberlegenen, in das man ,wiedergeboren' wird durch ein

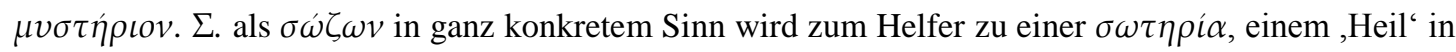
religiös abstrakterem, unirischem, geistigerem Sinn.' Dornseiff was drawing on Reitzenstein (1910), 25, 39. Similar ideas are found in Anrich (1894), 47-51 and Wobbermin (1896), 105-14.

${ }^{2}$ Some early works are e.g. Angus (1925), Macchioro (1930), Cumont (1929), Lagrange (1937). Some scholars e.g. Loisy (1914) identified ancient precedents for Christian ideas to undermine the position of the Roman Catholic Church. The question of ancient mysteries' influence on early Christianity has been a battlefield of theological wars: see Smith (1990), Graf and Johnston (2013), 58-61; Bremmer (2014), x-xi, ch. 6.

${ }^{3}$ E.g. Halliday (1925), 240-4; Willoughby (1929), 30-1, 227-8; Tarn (1952), 353-4. Frazer (1911-15) saw in many gods of ancient mystery cults the pattern of death and resurrection.

${ }^{4}$ Gardner (1911), 82-4; see similarly Gardner (1919), 81.
} 
Such interpretations have been criticized by Walter Burkert in Ancient Mystery Cults (1987), who argued against the other-worldly character of Greek mysteries and the universality of the 'dying and rising god'. Burkert's work remains one of the most important studies of ancient mysteries today; nevertheless it does not examine the actual use of the word soteria, which is central for determining whether Greek mystery cults were indeed 'Erlösungsreligionen'. A semantic analysis is all the more important given that modern scholarship often uses the English word 'salvation' loosely and confusingly in the modern, Christian, sense when referring to Greek antiquity. Consequently there is a danger that the Greek notion of soteria might have been attributed an eschatological aspect that was originally alien to it in ancient Greece.

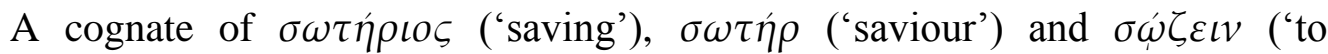
save'), ${ }^{5}$ the concept of $\sigma \omega \tau \eta \rho i \alpha$ first emerged in fifth-century literature in the context of the Persian Wars, ${ }^{6}$ and from then on was used in a variety of situations. What was 'saved' could be individuals, communities or objects; and the agent performing the saving could be human or divine. Groups and individuals could pray to the gods for soteria in all aspects of life, and some gods carried the epithet Soter or Soteira. ${ }^{7}$ For individuals, soteria might mean good health, escape from death, material prosperity, safe voyage, and smooth childbirth. For communities, it could be military victory, liberation from external domination, freedom from civil unrests, cure from plague and other natural disasters. In all these situations, soteria was concerned with practical help, protection, deliverance, and well-being in this world rather than the next.

This article will examine the language of soteria in the best-known mystery cults in ancient Greece. Lesser mysteries will not be discussed as little is known about their nature and benefits; ${ }^{8}$ nor will the Roman cult of Mithras, for which the evidence is mostly archaeological rather than textual. ${ }^{9}$ Focusing on the major mysteries in the Greek world, it will investigate whether Greek eschatological hopes were ever expressed in the language of soteria or in other terms, and what Soter and soteria meant when the words were used in relation to the gods of mysteries. ${ }^{10}$ It will be

\footnotetext{
${ }^{5}$ See Chantraine (1933), 78; Schwyzer (1934-71), vol. 1, 468-9; Chantraine (1968-80), vol. 4, 1084-5, s.v. $\sigma \tilde{\omega} \varsigma$; LSJ s.v. $\sigma \omega \tau \eta \dot{\rho} \rho \iota \varsigma$, ov II. 2. Some scholars take $\sigma \omega \tau \eta \rho i \alpha$ as a feminine substantive derived from the adjective $\sigma \omega \tau \eta \dot{\rho} \iota \varsigma$, but others (e.g. Kearns (1990), 324) think that it derives from the agent noun $\sigma \omega \tau \eta \dot{\eta} \rho$.

${ }^{6}$ Aesch. Pers. 508, 735, 797; Hdt. 4.98.3, 5.98.2, 5.119.2, 6.19.1, 6.104.2, 7.172.3, 8.118.2-3, 9.104.1.

${ }^{7} \mathrm{I}$ am preparing a study on this topic. Theoi Soteres are discussed by Graf (2017) in the present volume.

${ }^{8}$ Cyzicus had a well-known mystery cult of Kore Soteira (see n. 105), but little is known about its nature. The mysteries of Hecate on Aegina, traditionally thought to cure madness, are more recently said to have had an eschatological character. Nevertheless, Hecate is not called Soteira on Aegina, nor is the word soteria used in this context: see Paus. 2.30.2; Lucian, Navigium 15; Polinskaya (2013), 2906. On lesser mysteries, see Graf (2003) and other chapters in Cosmopoulos (2003).

${ }^{9}$ Mithras is not attested as Soter to my knowledge. A verse inscription in the Mithraeum of Santa Prisca in Rome has the line et nos servasti [...] sanguine fuso (CIMRM no. 485, 'and you saved us... by shedding the blood'). But in the absence of any surviving myth associated with this cult, and at a date when this might be influenced by Christianity, we must beware of attributing eschatological connotation into this inscription. On Mithraism, see e.g. the collection of sources in CIMRM; Hinnells (1994); Bianchi (1979); Turcan (1982); Clauss (1990).

${ }^{10}$ Some early interpretations, such as those of Anrich (1894) and Wobbermin (1896), have been criticized by Haerens (1948), 57-68. Yet Haeren's semantic analysis of soter and soteria is confined to Apuleius and Aelius Aristides, whereas epigraphic and literary sources are not examined.
} 
demonstrated that the character of soteria is primarily this-worldly: not even in mystery cults did it acquire an eschatological dimension, and its meaning remained markedly different from that in Christianity.

\section{The Eleusinian Mysteries}

The Eleusinian Mysteries were the most important and revered of all mystery cults in ancient Greece and were famous for their exceptional promise of a blessed afterlife. ${ }^{11}$ The earliest testimony to their eschatological dimension is in the Homeric Hymn to Demeter:

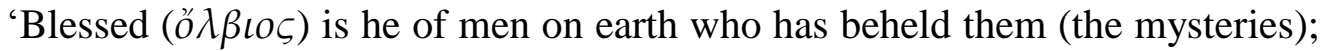
whereas he that is uninitiated in the rites, or he that has had no part in them, never enjoys a similar lot $(\alpha \tilde{i} \sigma \alpha)$ down in the musty dark when he is dead'. ${ }^{12}$

The word ó $\lambda \beta \iota \varsigma$ doubtless has the two-fold meaning of being 'prosperous' in this life and 'happy' in the next. The concerns for crops and the hereafter are intertwined, but the emphasis seems to be on the latter as the passage goes on to explain the uninitiated person's destiny in the netherworld. ${ }^{13}$ The promise of a blessed afterlife is repeated consistently in later sources; yet none of them uses the language of soteria or its cognates. Pindar and Sophocles describe the Eleusinian initiates as ó $\lambda \beta \iota$ $\tau \rho \iota \sigma o ́ \lambda \beta \iota \iota \iota$ respectively; Isocrates and Aelius Aristides refer to them as having

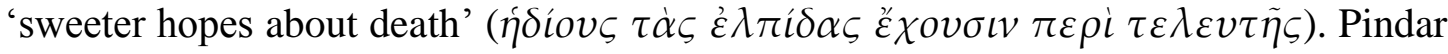

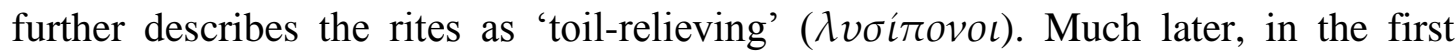
century B.C., Crinagoras thus describes the double benefits of initiation at Eleusis: 'your heart may be free of care while you live, and lighter when you go to the land of the dead'. ${ }^{14}$ Although there was no unity of belief among participants, the fact that the Eleusinian Mysteries had a prominent eschatological dimension cannot be denied. ${ }^{15}$

The Eleusinian goddesses are sometimes said to have borne the epithet Soteira, but this is based on the misinterpretation of two passages. A scene in Aristophanes' Frogs shows the Chorus of initiates marching in a procession while singing hymns to various deities, including to Soteira 'who affirms that she will keep the (Attic) land safe for all time to come' ( $\left.\dot{\eta} \tau \dot{\eta} v \chi \omega \dot{\omega} \rho \alpha v \sigma \omega \sigma \varepsilon \varepsilon \nu \phi \dot{\eta} \sigma^{\prime} \varepsilon \dot{\varepsilon} \zeta \tau \dot{\alpha} \varsigma \omega \omega^{\prime} \alpha \varsigma\right) .{ }^{16}$ That the rites in the parodos (lines 323-459) probably draw on those in the Eleusinian Mysteries has led to the widespread assumption that Kore Soteira or Demeter Soteira is meant. Demeter or Kore is again proposed as the Soteira in Aristotle's Rhetoric, in which Pericles asks the seer Lampon 'about initiation into the sacred rites of the Soteira' ( $\pi \varepsilon \rho i \tau \tilde{\eta} \varsigma \tau \varepsilon \lambda \varepsilon \tau \tilde{\eta} \varsigma \tau \tilde{\omega} v \tau \tilde{\eta} \varsigma \sigma \omega \tau \varepsilon i \rho \alpha \varsigma i \varepsilon \rho \tilde{\omega} v) .{ }^{17}$ When Lampon replied

\footnotetext{
${ }^{11}$ On the Eleusinan Mysteries, see Mylonas (1961); Graf (1974); Clinton, (1992); Sourvinou-Inwood (1997); Sourvinou-Inwood (2003); Parker (2005), 342-68; Bremmer (2014), ch. 1.

${ }^{12}$ Hymn. Hom. Cer. 480-3 (tr. Loeb). Other references to afterlife blessings in the Eleusinian Mysteries: Pind. fr. 131, 137; Soph. fr. 837, Isoc. 4.28; Aristid. Or. 4.28-29 Keil; Gow-Page, GP, Crinagoras $\mathrm{XXXV}=$ Anth. Pal. 11.42 .

${ }^{13}$ Richardson (1974), 310-11.

${ }^{14}$ Gow-Page, GP, Crinagoras XXXV = Anth. Pal. 11.42 (tr. Bowden (2010), 26).

${ }^{15}$ Cf. Burkert (1983), 294, Bowden (2010), 47-8, and Bremmer (2014), 18-20, all of whom downplay the eschatological aspect of the Eleusinian Mysteries.

${ }^{16}$ Ar. Ran. 378-81.

${ }^{17}$ Arist. Rh. 3.18, 1419a. Most manuscripts have $\sigma \omega \tau \varepsilon i \rho \alpha \zeta$, but some have $\sigma \omega \tau \eta \rho i \alpha \varsigma$.
} 
that it was not possible for those not initiated to be told about them, Pericles asked how Lampon could have known about them when he himself was uninitiated. As neither Pericles nor Lampon had been initiated into those sacred rites, the reference is unlikely to be to Eleusis. I have argued elsewhere that the Soteira in Aristophanes' Frogs is Athena, and that the most likely candidate Pericles is referring to is Kore Soteira in Cyzicus on the Propontis, who had a mystery cult but whose nature and blessings remain little known. ${ }^{18}$ If the identifications are correct, there would be no attestation of Demeter Soteira or Kore Soteira in Eleusis or Attica. ${ }^{19}$

\section{Samothrace}

Unlike the Eleusinian Mysteries, which offered hopes of a blessed afterlife but without using the word soteria, the cult of the Great Gods at Samothrace was closely connected with soteria but in a this-worldly sense. ${ }^{20}$ Cognate words of soteria recur in the sources, in reference to protection from perils at sea. Apollonius Rhodius' Argonautica mentions how the Argonauts put in at Samothrace in order to learn the rites and to 'sail over the chilling sea more safely' ( $\sigma \omega o ́ \tau \varepsilon \rho o \iota ~ \kappa \rho v o ́ \varepsilon \sigma \sigma \alpha v$ vi $\varepsilon \dot{\rho} \rho$ $\alpha \lambda \alpha v \alpha v \tau i \lambda \lambda o \iota v \tau o$ ). The $\mathrm{L}$ scholia explain as follows: 'if anyone is initiated into the rites (at Samothrace), he would be saved from storms at sea' ( $\hat{\alpha} \varsigma \varepsilon \dot{\imath} \tau \iota \varsigma \mu v v \theta \varepsilon i \eta \eta$, $\dot{v} v$ $\tau o \tilde{\iota} \varsigma \theta \alpha \lambda \alpha \sigma \sigma \alpha v \chi \varepsilon \varepsilon \mu \tilde{\omega} \sigma \iota \delta \iota \alpha \sigma \omega \zeta \varepsilon \tau \alpha \iota)$. Yet in explaining the word $\sigma \omega o ́ \tau \varepsilon \rho o \iota$, the scholia suggest that the protection offered by the rites was much broader than seafaring: 'for those initiated here are said to be heard in whatever they pray for'

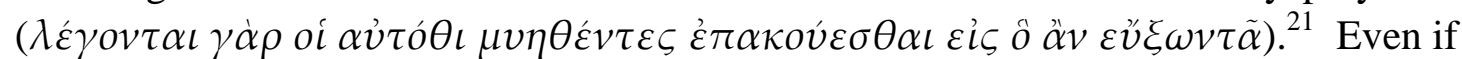
the scholia are right about this, however, they do not hint that the initiates would have prayed for post-mortem benefits. It has been suggested that the Samothracian mysteries might have later developed an eschatological dimension like those at Eleusis, but neither is this certain, nor is the language of soteria used. ${ }^{22}$

The experience of the Argonauts illustrates graphically how the Samothracian gods actually 'saved' worshippers when invoked in tempests. Diodorus relates how Orpheus, who alone was initiated in these rites, twice saved the Argo in a great storm. When the crew 'gave up hope of being saved' ( $\dot{\alpha} \pi \sigma \gamma \iota v \omega \sigma \kappa \varepsilon \iota v \tau \eta \dot{\eta} v \omega \tau \eta \eta \dot{\alpha} \alpha v)$, Orpheus offered prayers to the Samothracian gods for their deliverance ( $\pi \circ \iota \eta \sigma \alpha \sigma \theta \alpha \iota$ $\tau o \tilde{\iota} \varsigma \Sigma \alpha \mu o ́ \theta \rho \alpha \xi \iota \tau \dot{\alpha} \varsigma \hat{v} \pi \dot{\varepsilon} \rho \tau \tilde{\eta} \varsigma \sigma \omega \tau \eta \rho i \alpha \varsigma \varepsilon \dot{v} \chi \dot{\alpha} \varsigma)$. On both occasions the wind

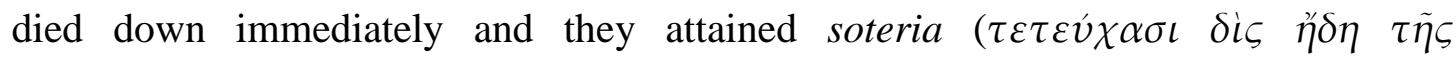

\footnotetext{
${ }^{18} \mathrm{Jim}$ (2015), 64-6. Unnamed Soteira is discussed by Graf in the present volume. On Kore in Kyzicus, see Hasluck (1910), 210-3; Robert (1978), 460-77 (156-73 at reprint).

${ }^{19}$ I.Eleusis $486=I G \mathrm{II}^{2} 4779$ from the imperial period attests to Soteres Theoi and Soteres Theai of the Roman emperors. But they seem to be gods and goddesses who protected the emperors, not Demeter and Kore specifically (cf. Clinton in I.Eleusis 486).

${ }^{20}$ On the Samothracian mysteries, see Cole (1984); Clinton (2001); Clinton (2003); Dimitrova (2008). The literary sources are conveniently collected in Lewis (1959). The literary and epigraphic evidence will be discussed in Clinton (forthcoming).

${ }^{21}$ Apoll. Rh. 1.916-20; Schol. Apoll. Rh. 1.917b, 918a, 918e (tr. adapted from Lewis). See similarly Schol. vet. Ar. Pax. 278, according to which those initiated are believed 'to be saved from troubles and

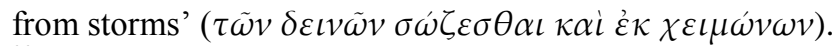

${ }^{22}$ This is based on an epitaph for a Samothracian initiate who had also been initiated at Eleusis; it ends

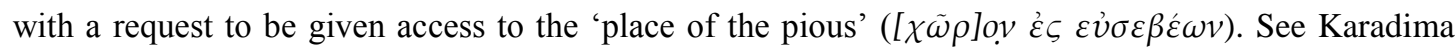
and Dimitrova (2003); Dimitrova (2008), no. 29; Parker (2011), 253-4.
} 
$\sigma \omega \tau \eta \rho i \alpha \varsigma) .{ }^{23}$ In these occurrences soteria refers to deliverance and physical survival from perils at sea.

Initiates fortunate enough to return safely from a voyage would often commemorate their deliverance with a permanent offering. One offering comes from Koptos in Egypt in the third century B.C., and another from Apameia in Asia Minor (undated):

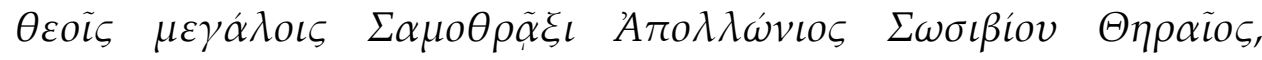

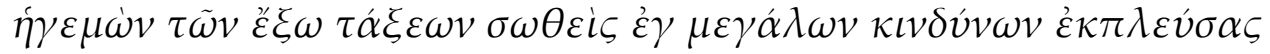
$\dot{\varepsilon} \kappa \tau \tilde{\eta} \varsigma^{\prime} E \rho v \theta \rho \alpha \dot{\alpha} . \theta \alpha \lambda \dot{\alpha} \sigma \sigma \eta \varsigma, \varepsilon \dot{v} \chi \dot{\eta} v$

'To the Great Gods of Samothrace, Apollonios son of Sosibios of Thera, commander of troops, having been saved from great dangers sailing out of the Red Sea, in fulfilment of a vow'. ${ }^{24}$

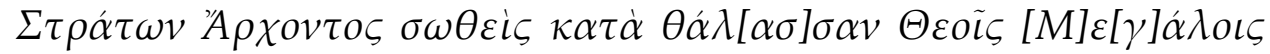 $\Sigma \alpha[\mu] o ́ \theta \rho[\alpha] \xi \iota v \chi \alpha \rho \iota \sigma \tau \eta \dot{\rho} \iota$ เ \\ 'Straton, son of Archon, saved from sea, dedicated (this) to the Great Gods of Samothrace as a thank-offering'. ${ }^{25}$}

Apollonios was apparently a Ptolemaic commander from Thera; he had probably been initiated at Samothrace and then delivered from perils in the Red Sea while on military service. Many more dedications, large and small, must have been erected in the sanctuary of the Great Gods at Samothrace. When confronted with the abundance of votive offerings in this shrine, the atheist Diagoras of Melos is said to have famously retorted that 'there would have been far more if those who were not saved had set up offerings' $(\pi \circ \lambda \lambda \tilde{\omega} \ddot{\alpha} v \tilde{\eta} \nu \pi \lambda \varepsilon \dot{\varepsilon} \omega, \varepsilon \dot{\imath} \kappa \alpha \dot{\imath}$ oi $\mu \dot{\eta} \sigma \omega \theta \dot{\varepsilon} \nu \tau \varepsilon \zeta \dot{\alpha} v \varepsilon \tau i \theta \varepsilon \sigma \alpha v){ }^{26}$ Despite initiation, then, it was up to the gods whether or not to save, and many were drowned at sea. As the scholia put it, initiates are 'more apt to be saved' ( $\mu \tilde{\alpha} \lambda \lambda o v$ $\sigma \omega \zeta \varepsilon \sigma \theta \alpha \iota)$ than the uninitiated, but soteria was by no means guaranteed. ${ }^{27}$

As the dedications from Koptos and Apameia show, the Samothracian gods are usually called Theoi Megaloi or Theoi Megaloi Samothrakes in inscriptions. ${ }^{28}$ Rarely are they called Soteres: a rare instance is found in one of the Orphic Hymns, in which they are associated with the Kouretes, Korybantes, and the Dioscuri. Here they

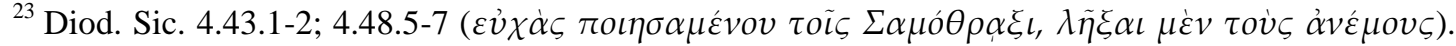
See also the parody in Alexis fr. 183 = Ath 10.421d-e. For other statements of how the Samothracian gods saved (but without use of the words sozein or soteria), see e.g. Diod. Sic. 5.49.5, Schol. vet. Ar. Pax. 277b, Schol. Apoll. Rh. 1.917b.

${ }^{24}$ I.Portes no. 48; OGIS 69 (246-221 B.C.?). A Ptolemaic garrison is attested in Thera in the reign of Ptolemy III (OGIS 59). Cf. Bernand in I.Portes, who explains the kiv $\delta v v o \iota$ in terms of dangers in traversing the eastern deserts.

${ }^{25}$ MAMA VI p. 145, no. 94 (no text); CIG 3961 (undated); Cole (1984), appendix I, no. 54. The text in $C I G$ has $[\theta \varepsilon] o \tilde{\iota} \varsigma \mu \varepsilon[\gamma] \dot{\alpha} \lambda o \iota \varsigma$ (without $\Sigma \alpha[\mu] o ́ \theta \rho[\alpha] \xi \iota v$ ) and is supplemented in slightly different places. Here I reproduce the more recent edition from Cole (1984).

${ }^{26}$ Diog. Laert. 6.59 (tr. Loeb) (the statement has been variously attributed to Diogenes of Sinope and to Diagoras of Melos); Cic. Nat. D. 3.89.

${ }^{27}$ Schol. Apoll. Rh. 1.918e.

${ }^{28}$ Cole (1984), 1-2, notes that they are called Theoi Megaloi or simply Theoi when referred to in local inscriptions from Samothrace, and that Samothrakes is only used when mentioned outside Samothrace.
} 
are referred to as 'illustrious saviours of the universe' (line 3: kó $\sigma \mu o v \sigma \omega \tau \tilde{\eta} \rho \varepsilon \varsigma$ $\dot{\alpha} \gamma \alpha v o i$ ) and as 'saving' (line 24: soterioi) probably by association with the Dioscuri, who often carried this epithet. ${ }^{29}$ Despite ancient and modern conjectures, the 'real' name and identity of the Samothracian gods remain unresolved. ${ }^{30}$

\section{The Dionysiac Mysteries}

Unlike the Eleusinian Mysteries, which had to be undertaken at Eleusis, the mystery cults of Dionysus are attested in different parts of the Greek world. Euripides' Bacchae dramatises the aetiological myth of their foundation in Thebes. One scene shows Dionysus in disguise, trying to persuade the young king Pentheus to go to the mountain to witness what the maenads are doing: 'I will go as your escort

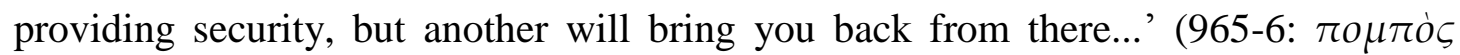

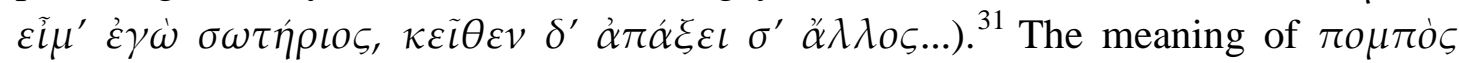
$\sigma \omega \tau \eta \dot{\rho} \iota \varsigma_{\varsigma}$ (literally a 'saving escort') has been variously interpreted. ${ }^{32}$ Seaford argues that the play is itself a symbolic representation of initiation into the mysteries of Dionysus: the $\pi \circ \mu \pi \dot{\alpha} \varsigma$ represents the 'initiand-leader' ( $\mu v \sigma \tau \alpha \gamma \omega \gamma o ́ \varsigma)$ who would lead an initiate to the sanctuary, and Pentheus' death represents the symbolic death an initiate would undergo in the course of initiation. The 'security' provided by the $\tau о \mu \pi \dot{s} \varsigma \sigma \omega \eta \dot{\rho} \iota \varsigma_{\text {, }}$ according to Seaford, may imply 'mystic salvation' provided to the initiate, here represented by Pentheus. ${ }^{33}$ However, when Dionysus describes himself as $\pi о \mu \pi \dot{\alpha} \varsigma \sigma \omega \tau \eta \dot{\rho} \rho\llcorner\varsigma$, the effect is deeply ironic: he provides the opposite to soteria, as he leads Pentheus to Mt. Kithairon only to be torn apart by the maenads. The surface meaning of soterios is not eschatological, and without analogies for the word soterios in an other-worldly sense, there is no reason to detect a second, disguised meaning here. Seaford's ritualistic approach makes him predisposed to finding ritual meaning behind his characters' experiences. To read $\pi \circ \mu \pi \dot{\alpha} \varsigma$ as $\mu v \sigma \tau \alpha \gamma \omega \gamma o ́ \varsigma$, and to see in soterios 'mystic salvation', offers an interpretation that fits the tenor of his exegesis of this play and of Greek tragedy in general.

Although Dionysus' association with the afterlife is attested as early as the fifth century in archaeological and literary evidence, ${ }^{34}$ eschatological hopes are of

\footnotetext{
${ }^{29}$ Orph. Hymn 38.

${ }^{30}$ The Theoi Megaloi at Samothrace are sometimes associated with the Cabiri, who were honoured together with a Mother goddess in the Theban mysteries at the Cabirion; yet not much is known about the nature and benefits of this cult. On the Samothracian Theoi Megaloi and their relationship with the Cabiri and the Dioscuri, see Hdt. 2.51; Hemberg (1950); Cole (1984); Burkert (1985), 281-5. On the Theban Cabiri, see Schachter (1981-94), vol. 2, 88-110, esp. 110; Schachter (2003).

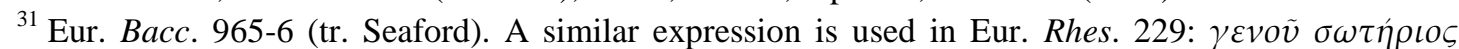

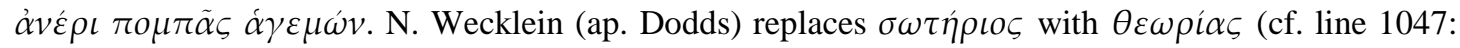
$\pi о \mu \pi \dot{s} \varsigma \theta \varepsilon \omega \rho i \alpha \varsigma)$. J.S. Reid ap. Sandy (1900), suggests $\sigma \omega \tau \eta \rho i \alpha \varsigma$ on the basis of line 1047.

${ }^{32}$ Dodds (1960), 196: 'it is true that P. gets there in safety' (his italic). Roux (1970-2), vol. 2, 538-9, sees in Pentheus the pharmakos who dies for the city of Thebes and thereby expiates the god's wrath, and he sees Dionysus as the soter who 'saves' Thebes by being satisfied with one human victim only. Kirk (1979) translates: 'Follow, and I shall go as your escort and protector'.

${ }^{33}$ Seaford has expressed similar views in a series of publications: Seaford (1981); Seaford (1994), esp. 276, 284; Seaford (1996), 226: 'The security, accordingly, may imply mystic salvation'. His ritualistic approach has been criticised by Friedrich (2000).

${ }^{34}$ See the bone tablets from fifth-century Olbia, one of which combines the nouns Bios $\theta \alpha \dot{v} \alpha \tau o \varsigma$ Bios $\dot{\alpha} \lambda \dot{\eta} \theta \varepsilon \iota \alpha$ with the phrase $\Delta \iota{ }^{\prime}(v v \sigma o \varsigma)$ 'O $\rho \phi \iota \kappa o \iota$ or 'O $\rho \phi \iota \kappa o ́ v$; this is reproduced in Graf and Johnston (2013), appendix IV no. 1; Hdt. 2.81. Cf. the plot of Aesch. Bassarae.
} 
little or no concern in Euripides' Bacchae. Even if they sometimes appear to lie under the surface, they were not expressed by the word soteria. ${ }^{35}$ Much more prominently associated with eschatology are the so-called Orphic gold tablets, dating from the late fifth century B.C. to the second century A.D. Deposited in graves of initiates, the small tablets were inscribed with ritual instructions to guide the dead to the underworld and to a blessed afterlife. None of the tablets published so far uses the word soteria. The closest we get is an allusion to Dionysus' 'release' of the dead in two texts from the city of Pelinna in Thessaly:

Now you have died and now you have come into being, $\mathrm{O}$ thrice happy one, on this same day.

Tell Persephone that the Bacchic One himself released ( $\left.\varepsilon^{\prime} \lambda v \sigma \varepsilon\right)$ you.

Bull, you jumped into milk.

Quickly, you jumped into milk.

Ram, you fell into milk.

You have wine as your fortunate honour.

And below the earth there are ready for you the same rites $(\tau \dot{\varepsilon} \lambda \varepsilon \alpha)$ as for the other blessed one. ${ }^{36}$

These two tablets, each in the shape of an ivy leave, were found placed symmetrically on the chest of a woman buried in the late fourth century B.C. The role of Dionysus and the 'release' he provided have been interpreted by Graf with the help of an Orphic fragment, in which Damascius explains Dionysus' epithet Lyseus:

Dionysus is responsible for deliverance $(\lambda \dot{v} \sigma \iota \varsigma)$ and for this very reason the god is called Deliverer ( $\Lambda v \sigma \varepsilon v ́ \varsigma)$. And Orpheus says:

People send perfect hecatombs

in all seasons during the whole year,

and they perform rites, seeking deliverance $(\lambda \hat{v} \sigma \iota \varsigma)$ from unlawful ancestors.

But you [Dionysus], having power over them, whomever you wish

You will deliver from difficult suffering and limitless frenzy

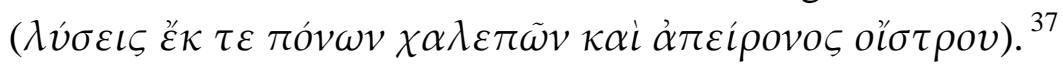

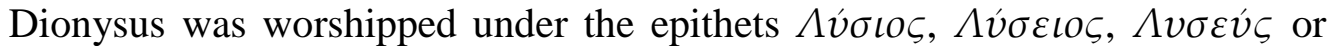
Avaĩos ('deliverer', 'releaser', 'loosener') in various parts of the Greek world, ${ }^{38}$ and Aelius Aristides says that there was nothing - be it disease, wrath, or any fortune from which Dionysus could not provide release. ${ }^{39}$ Particularly relevant for Dionysiac initiates is his power to cure madness and sufferings. Plato associates Dionysus with 'ritual madness' (telestike mania): anyone rightly possessed by it could secure 'release $(\dot{\alpha} \pi \alpha \lambda \lambda \alpha \gamma \eta)$ from the greatest diseases and sufferings at one time arising

\footnotetext{
${ }^{35}$ E.g. the words 'happy' $(\mu \alpha \dot{\kappa} \alpha \alpha \rho)$ and 'blessed' ( $\left.\varepsilon \dot{v} \delta \alpha i \mu \omega v\right)$ in Eur. Bacc. 72.

${ }^{36}$ Graf and Johnston (2013), no. 26a, b (tr. adapted from Graf and Johnston). Text a is longer than text b: the text quoted here is that of text a. Discussed also in Graf (1993).

${ }^{37}$ OF 350 (tr. Graf and Johnston p. 132).

${ }^{38}$ E.g. Orph. Hymn. 42.4 (Lyseios Iacchos); 50.2 (Lysios), 50.8 (Lysios), 52.2 (Lyseus); Paus. 2.2.6-7 (Lysios, in Corinth), 2.7.5-6 (Lysios, in Sicyon), 9.16.6 (Lysios, in Thebes); IG V.2 287 (Lyaios, in Mantinea).

${ }^{39}$ Ael. Arist. 41.7 Keil. On Dionysus Lysios, see also Versnel (1990), 166, 193-4 n. 331; Cole (2007), 339-40; Graf (2010). On Dionysus and eschatology, see Graf (1993).
} 
from ancient causes of wrath in some of the families' and 'release $(\lambda \dot{v} \sigma \iota \varsigma)$ from the present evils'. ${ }^{40}$ The 'sufferings' ( $\pi$ óvol) mentioned by Plato and Orpheus (ap. Damascius) can refer to both illness in life and punishment after death. Dionysus Lysios must have been the most important among the 'gods of deliverance' (theoi lusioi) who, according to Plato, had great power to protect one against punishment after death. ${ }^{41}$

Yet how did humanity incur post-mortem punishments? The Orphic myth of Dionysus tells how Dionysus, born from Zeus and Persephone, was dismembered by the Titans but then reborn. ${ }^{42}$ Mankind was stained with the crime of the Titans, who were their most likely 'ancestors' referred to in Orpheus (ap. Damascius) and Plato. The 'release' in the Pelinna tablets can be best understood in this light: initiation into Dionysaic rites could liberate the soul from the ancestral blood-guilt that all mankind had inherited from the Titans, which put humanity in Persephone's bad graces. By contrast to non-initiates who still bore such burdens, the soul of the initiated could 'tell Persephone that the Bacchic One himself released you', that is, it could declare its special, 'liberated', status to the queen of the netherworld, and thereby enjoy a better lot in the hereafter.

Similar ideas are found in several other gold tablets, from Thurii and Rome, which refer to the deceased's pure status ( $\kappa \alpha \theta \alpha \rho o ́ \varsigma)$ and, in two of them, requital ( from the pollution originating from the crime of the Titans. Yet the language used is that of 'purity' and 'release', not 'salvation' (soteria). Although Dionysus could mediate with the underworld powers on behalf of his initiates, the fact remains that the benefit referred to in the tablets is a 'pure' or 'freed' status, not soteria, and the god concerned is Dionysus Lysios, not Dionysus Soter.

Despite their central concern with the afterlife, then, none of the gold tablets published so far mentions soteria. The language of 'saving' is used, however, in a fragmentary papyrus from Gurôb dated to the late third century B.C., which has a mixture of invocations and prayers for a ritual probably connected to Dionysus, including two prayers to the underworld deities to 'save' the initiate:

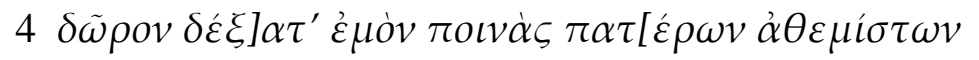

$5 \sigma \tilde{\omega} \iota \sigma o ́ v . \mu \varepsilon$ B $\rho \mu \omega \dot{\omega} \mu \varepsilon[\gamma \alpha \dot{\alpha} \lambda \eta$

[Receive my gift] as the payment for [lawless] ance[stors]

Save me, Brimo, gr[eat

\footnotetext{
${ }^{40}$ Pl. Phaedrus 244d, 265b (tr. Cole (2007), 339).

${ }^{41}$ Pl. Rep. $366 \mathrm{a}-\mathrm{b}=$ OF 574.

${ }^{42}$ Olympiodorus in Pl. Phd. 1.3 = OF 304 I, 318 III, 320 I. The myth is discussed in Graf and Johnston (2013), ch. 3. Some scholars see it as a third-century invention: see Dodds (1951), 155-6; cf. Bernabé (2002). Recently Edmonds III (2013), chs. 6 and 9, argues for an Orphism without original sin and without a fixed cannon of Orphic doctrines, with R. Parker, BMCR 2014.07.13. A fourth-century Apulian funeral krater, depicting Dionysos shaking hands with Hades enthroned opposite a standing Persephone, has been interpreted by Johnston and McNiven (1996) as the first iconographic representation of Orphic doctrines referred to in the gold tablets.

${ }^{43}$ Graf and Johnston (2013), nos. 5-7, 9 = Zuntz A 1-3, A 5, with commentary in Bernabé and Jiménez San Cristóbal (2008). The relationship between 'purification' and 'salvation' (in the eschatological sense) is discussed in Parker (1983), ch. 10.
} 


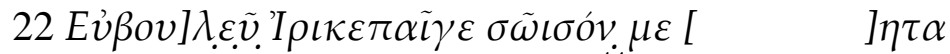 Eubou]leus, Irikepalos, save me ${ }^{4 \dot{4}}$}

The ritual context in which the papyrus was used remains uncertain. Line 5 contains an appeal to Brimo to save the initiate, who in the preceding line mentions his payment for his ancestors. Unfortunately this column is preserved only on the righthand edge, so we do not know how much of each line is lost, and how the rolvai in line 4 relate (if at all) to the 'saving' in lines 5 and $22 .{ }^{45}$ Brimo is the epithet of various chthonic deities including Persephone, Rhea, Demeter and Hecate. She features in the sacred cry at the Eleusinian Mysteries, and also appears in a gold tablet from Pherae from the second half of the fourth century B.C., where she has been identified with Persephone. ${ }^{46}$ The Pherae tablet uses her name as a password ( $\sigma \hat{v} \mu \beta o \lambda o v)$; it further mentions the initiate's entry into the holy meadow ärolvos $\gamma \dot{\alpha} \rho \delta \mu v \sigma \tau \eta \varsigma$ ('for the initiate is freed from payment'), presumably meaning that he is now free from the roıv $\eta$ incurred by ancestral guilt because he has been initiated. ${ }^{47}$ The papyrus can further be compared to a fragment of Pindar, in which Persephone is

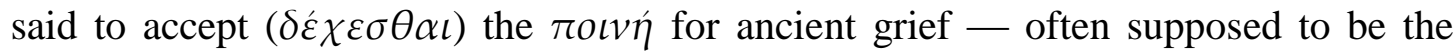
grief caused by the dismemberment of her son - and to give these individuals a blessed lot in the afterlife. ${ }^{48}$ Nevertheless, comparable texts do not get us very far in establishing the sense of $\sigma \tilde{\omega} \iota \sigma o ́ v$. The Gurôb papyrus is unfortunately too fragmentary to lend itself to any reliable interpretation. Analysis is hindered further by the possible influence of other mystery cults on the papyrus' text, ${ }^{49}$ so that any attempt to interpret it in the light of the Orphic myth of Dionysus and of the Pherae tablet may be misleading. But given the absence of words of 'saving' in the gold tablets, it is highly unlikely that $\sigma \tilde{\omega} \iota \sigma o ́ v$ had an eschatological significance in the papyrus.

From Asia Minor around the second century A.D, the so-called Orphic hymns are also connected to Dionysiac mysteries, yet they are both much later than the gold tablets and betray rather different concerns. ${ }^{50}$ Although they presuppose the Orphic theogony and frequently refer to mystai in the sacred teletai, the hymns contain surprisingly little on eschatology. ${ }^{51}$ The hymns frequently use the epithets Soter and

\footnotetext{
${ }^{44}$ OF 578; Graf and Johnston (2013), 150-5, appendix iv, no. 3 (tran.); Hordern (2000).

${ }^{45}$ Bernabé in the app. crit. of $O F 578$ refers for parallels to OF 830a (= SEG XXXVIII 1837; ZPE 72 (1988), 245-59), a love-charm on a lead tablet of the third or fourth century A.D., which reads $[\sigma \tilde{\omega}] \sigma o ́ v$

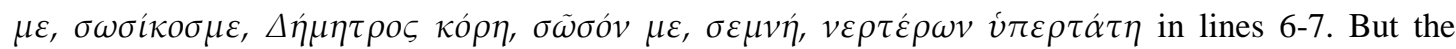
meaning of 'to save' in the love-charm seems to be different from that in the Gurôb papyrus. Bernabé further compares the papyrus to words of sozein and lyein in the Orphic hymns as studied by Morand (2001), 218ff., which, as we shall see, have no eschatological connotation.

${ }^{46}$ Brimo: see Burkert (1983), 289, n. 71. Eleusis: Hippol. Haer. 5.8.40. Pherae tablet: Graf and Johnston (2013), no. 27, with appendix ii (where Brimo is discussed).

${ }^{47}$ See Bernabé and Jiménez San Cristóbal (2008), 155-6 (on Brimo), 157-8 (on äroıvo ).

${ }^{48}$ On atonement to Persephone, see Pind. fr. 133, with Rose (1936); Rose (1943). Cf. Edmonds III (2013), 304ff, who associates her grief with her rape by Plouton.

${ }^{49}$ West (1983), 171; Horden (2000), 132-3.

${ }^{50}$ On the Orphic hymns, see e.g. A.F. Morand (2001), Études sur les Hymnes orphiques (Leiden); F. Graf (2009), 'Serious Singing: the Orphic Hymns as a Religious Text', Kernos 22, 169-82; M. Herrero de Jáuregui (2015), 'The Poet and His Addressees in Orphic hymns', in A. Faulkner and O. Fodkinson (eds.), Hymnic Narrative and the Narratology of Greek Hymns (Leiden), 224-43.

${ }^{51}$ Terminology related to mysteries in the Orphic Hymns is studied in Morand (2001), 140ff. and $235 \mathrm{ff}$. Eschatological themes are discussed in her ch. 4.
} 
Soteira in relation to different gods, along with the cognate verb sozein and adjective soterios (but not the abstract noun soteria). However, contextual information shows that the 'saving' concerns matters in this life rather than the next. The benefits prayed for may vary with each hymn: some recurrent themes are agriculture abundance, prosperity, peace, good health, a long life, and a good end to life. ${ }^{52}$ Thus Prothyraia was invoked as the 'saviouress of women' $(\theta \eta \lambda \varepsilon \iota \tilde{\omega} v \sigma \omega \dot{\omega} \varepsilon \iota \rho \alpha)$ to free them from pains of childbirth; Asclepius was Soter in his capacity to ward off pains and diseases; Poseidon (not called Soter) was asked to 'save the foundations of the earth and ships moving at full tilt' ( $\check{\delta} \rho \alpha v \alpha \gamma \tilde{\eta} \varsigma \sigma \omega \zeta o \iota \varsigma \kappa \alpha i v \eta \tilde{\omega} v \varepsilon \tilde{v} \delta \rho o \mu o v \delta \rho \mu \eta \dot{v})$. The Kouretes and Leukothea were called 'Saviours' for warding off maritime dangers; Palaimon was similarly invoked as Soter 'to save initiates on land and at sea' ( $\kappa \alpha i \sigma \omega \zeta \varepsilon \iota v$ $\mu v \dot{\sigma \tau} \alpha \varsigma \kappa \alpha \tau \dot{\alpha} \tau \varepsilon \chi \theta o ́ v \alpha \kappa \alpha i \kappa \alpha \tau \dot{\alpha} \pi o ́ v \tau o v) .{ }^{53} \mathrm{~A}$ few hymns end with the request that the god or goddess might 'save' his/her initiates, meaning their general protection or well-being. ${ }^{54}$

What we have seen in this section, under the subheading of Dionysus, involves different kinds of religious phenomena and texts expressing rather different concerns. We ought to recognize, therefore, that individuals under the broad umbrella of 'Dionysiac worshippers' might not share the same experiences and expectations. The variety of ritual practices related to Dionysus, as well as the diversity of contexts with which the god was associated, make it dangerous to read the expectation of one group (such as lysis in the Pelinna tablet) into the prayer of another group (as in the soteria prayed for by the priests). ${ }^{55}$

\section{Plato's eschatological myths}

The language of 'liberation' and 'purity' is prominent in Plato also, but he uses the terms in a very different sense from that in the gold tablets. While the Dionysiac initiates were 'released' from their ancestral guilt and made 'pure' by initiatory rituals, for Plato 'purity' was to be achieved by practising philosophy in life, which would have ramifications on the next. Plato discusses the destiny of the soul in various eschatological myths. ${ }^{56}$ The actual treatment of the soul varies from one myth to another, but the central idea is that the souls of human beings would all face some form of judgment after death and receive either rewards or punishments, depending on one's conduct in life. Unlike in Orphic mythology, the crime for which one had to

\footnotetext{
${ }^{52}$ Agriculture: Orph. Hymn 43, 82; prosperity: 60, 72, 73, 84; peace: 10.30, 17.10, 23.8; health: 10.30, 15.10, 23.8, 40.20; longetivity: 87.11; good end to life: $13,57,67,73$.

${ }^{53}$ Childbirth: Orph. Hymn 2.3, 2.14 (Prothyraia); diseases 67.8 (Asclepius); earthquake: 17.9 (Poseidon). Seafaring: 17.9 (Poseidon) (tr. Athanassakis and Wolkow), 38.3, 38.5, 38.24 (the Kouretes), 74.4, 74.7, 74.9 (Leukothea), 75.5, 75.7 (Palaimon); protection on land: 75.5 (Palaimon). A few cases do not specify the nature of the 'saving': Orph. Hymn 14.8, 14.12 (To Rhea), 27.12 (Metre Theon as soteira of Phrygia). Artemis is described as 'saviouress to all initiates' ( $\sigma \omega \dot{\omega} \varepsilon \iota \rho \alpha \mu v \dot{\sigma} \sigma \eta \sigma \iota v \alpha \check{\pi} \alpha \sigma \iota v)$ in 36.13 .

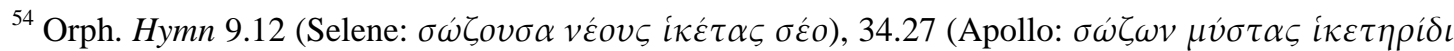
$\phi \omega v \tilde{\eta}), 85.10$ (Sleep: $\sigma \omega \zeta o v \tau^{\prime} \varepsilon \dot{v} \mu \varepsilon v \varepsilon \omega \varsigma \mu \dot{v} \sigma \tau \alpha \varsigma$ ).

${ }^{55}$ The fine study of S.G. Cole (1993), 'Voices from Beyond the Grave: Dionysus and the Dead', in T.H. Carpenter and C.A. Faraone (eds), Masks of Dionysus (Ithaca, London), 276-95, demonstrates that the eschatological themes so prominent in the gold tablets are manifestly absent in the funeral inscriptions from the late Hellenistic and Roman imperial periods mentioning Dionysus or Dionysiac rituals.

${ }^{56}$ Pl. Grg. 492e-493b, 523a-527e; Phd. 61a-69d, 80d-83e, 107c-115a; Phdr. 246a-249d; Resp. 359d366b, 614b-621d; and Ti. 42b-d, 90e-92c. On Plato's eschatological myths, see Edmonds III (2003), ch. 4; Bernabé (2013); Ward (2013).
} 
achieve expiation after death is not an original sin, but the offences committed during one's own lifetime. The word sozein and soteria are used in relation to the soul in two passages. ${ }^{57}$

One of these concerns the myth of Er, which relates the Pamphylian's journey to the netherworld and his return to describe what happens there. Er reports how the souls would need to expiate their crimes ten times for each one and each time for a hundred years, whereas those which were good would receive rewards. When the sufferings were over, the souls would journey through the meadow and choose their next life before the Spindle of Necessity in the presence of the three Morai. ${ }^{58}$ Plato ends the myth by saying that 'the story has been preserved ( $\dot{\varepsilon} \sigma \omega \theta \eta)$ and has not been lost, and it would save us ( $\dot{\eta} \mu \tilde{\alpha} \varsigma \grave{\alpha} v \sigma \hat{\omega} \sigma \varepsilon \varepsilon \varepsilon v)$ if we follow it and we shall make a successful crossing of the river Lethe and shall not pollute (ov $\mu \iota \alpha v \theta \eta \sigma o ́ \mu \varepsilon \theta \alpha$ ) our souls'. ${ }^{59}$ At first sight it seems to mean that the myth would spare us from condemnation in the underworld. But as the last phrase $\tau \dot{\eta} v \quad \psi v \chi \eta \dot{v} v$ ov $\mu \iota \alpha v \theta \eta \sigma o ́ \mu \varepsilon \theta \alpha$ hints, Plato is ultimately concerned about how we live this life rather than how we achieve a better lot in the next. Postmortem rewards and punishments are mentioned only insofar as they can provide incentive for moral conduct and deterrent from unjust behaviour in this world. Plato tells the myth so that, if we heed it, it can 'save' us from the danger of doing wrong and polluting our soul while we live and, as a result, from retribution after death. As Plato goes on to say, 'if we follow what I say... we shall always keep to the upward path and we shall practice justice with intelligence in every way... both here and on our thousand-year journey... ${ }^{, 60}$ When Plato concludes that the myth of Er would save us, therefore, the 'saving' concerns this life as much as the next.

An interesting use of soteria appears in Phaedo, in which Socrates persuades his disciples that the true philosopher welcomes death. Plato conceives of death as the soul's ultimate 'release' and 'separation' from the body ${ }^{61}$ - an enclosure which, while we live, safeguards or keeps the soul safe $(\sigma \omega \zeta \varepsilon \iota v)$ like a prison. ${ }^{62}$ Because the soul is immortal and its destiny after death is closely informed by the habits it has acquired during its sojourn in the body, while alive one should keep the soul 'pure' from the body and avoid contamination by its desires, and this can only be achieved

\footnotetext{
${ }^{57}$ Pl. Resp. 621c; Phd. $107 \mathrm{c}-\mathrm{d}$.

${ }^{58}$ In Pl. Leg. 960c, one of the three Morai, Atropos, is called the 'Third Soteira' ( $\left.\tau \rho i ́ \tau \eta \sigma \omega \tau \varepsilon \iota \rho \alpha\right)$. Atropos is thus called not because she has anything to do with the 'saving' of souls, but presumably because her role came third in order, that is, she completes the work of the other two Moirai in making the assignment of each soul to its new life irreversible.

${ }^{59} \mathrm{Pl}$. Resp. 621c (tr. Loeb). Although all souls would drink from the river Lethe according to the myth of Er, 'those not saved by their good sense drank more than their measure' and forgot everything

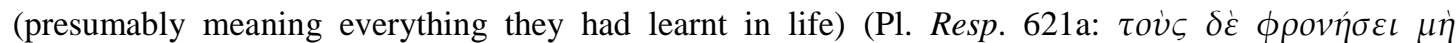

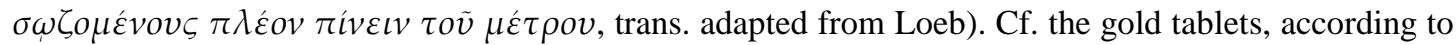
which initiates should drink from the Lake of Mnemosyne, implying that they should avoid the Lake of Lethe.

${ }^{60}$ Pl. Resp. 621c-d (tr. Loeb).

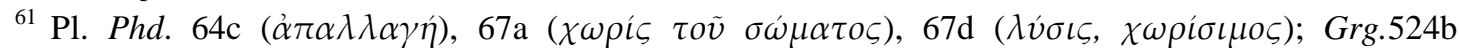
$(\delta \iota \alpha ́ \lambda v \sigma \iota \varsigma)$.

${ }^{62}$ See Pl. Cra. 400b-c on the etymology of $\sigma \tilde{\omega} \mu \alpha$ : some derive it from $\sigma \tilde{\eta} \mu \alpha$ ('tomb' or 'maker'), whereas Socrates prefers Orpheus' derivation of it from $\sigma \omega \zeta \omega$ in the sense of 'to keep safe'. See also Dodds (1951), 169-70 n. 87.
} 
by living a virtuous life. To Plato, virtues such as truth, self-restraint, justice, courage and wisdom all constitute a kind of 'purification' (69b-c: $\kappa \alpha \dot{\alpha} \theta \alpha \rho i \varsigma)$, which he defines as a process of 'separating' (67c: $\chi \omega \rho i \zeta \varepsilon v v)$ or 'freeing' $(67 \mathrm{~d}$ : $\dot{\varepsilon} \kappa \lambda \dot{v} \varepsilon v v)$ the soul from the body. Philosophy, to Plato, is a kind of initiation that purifies the soul. Socrates in Phaedo tells how the souls which had practised philosophy rightly would depart this world pure and enter into communion with the gods, whereas the defiled and impure ones would wander about and undergo cycles of reincarnation. $\mathrm{He}$ concludes that:

'For if death were an escape from everything, it would be a boon to the wicked, for when they die they would be freed from the body and from their wickedness together with their souls. But now, since the soul is seen to be

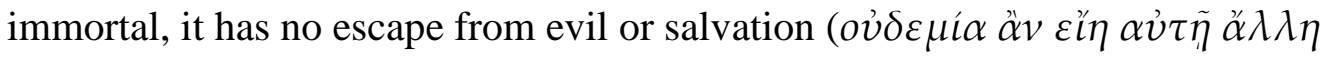

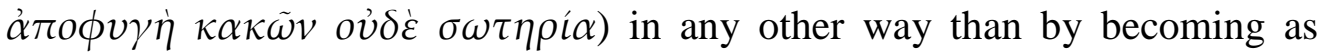
good and wise as possible. For the soul takes with it to the other world nothing but its education and nurture, and these are said to benefit or injure the departed greatly from the beginning of his journey thither. ${ }^{63}$

Soteria here cannot mean the preservation of life and avoidance of death (as the philosopher is glad to die), nor can it mean the continued existence of the soul (which is immortal). Here it serves as the positive equivalent of 'escape from evil' ( $\dot{\alpha} \pi \sigma \phi v \gamma \dot{\eta}$ $\kappa \alpha \kappa \tilde{\omega} v)$ in the same line, that is, the soul's escape from post-mortem condemnation. It is in the same sense that Proclus uses soteria when commenting on a myth in Plato's Timaeus, according to which those who have yielded to their bodily passions would be condemned to reincarnation: ${ }^{64}$

'This one salvation of the soul is offered by the Demiurgus, liberating $(\dot{\alpha} \tau \alpha \lambda \lambda \dot{\alpha} \tau \tau o v \sigma \alpha)$ her from the circle of generation and from many wanderings and from a never-ending life, the ascent of the soul to the intellectual form and the flight from all things which have attached to us from birth'. ${ }^{65}$

Both passages use soteria to refer to the soul's deliverance from sufferings after death, specifically from the endless cycle of reincarnation. Following Plato, Proclus thinks that the soul can be liberated from eternal condemnation only by pursuing the intellect and avoiding earthly contacts which the body is born with. If soteria was usually used by the Greeks in relation to escape from dangers (potential or real) in life, Plato and Proclus were transposing the word from earthly dangers to even greater dangers awaiting the unjust after death. This is the only instance in Plato - and, to the best of my knowledge, in the entire Greek corpus - where soteria applies to the underworld; words of soter, sozein and soteria permeate his writing and have a wide range of

\footnotetext{
${ }^{63} \mathrm{Pl}$. Phd. $107 \mathrm{c}-\mathrm{d}$ (tr. adapted from Loeb).

${ }^{64} \mathrm{Pl}$. Ti.42a-d (the word soteria is not used by Plato here). Plato is inconsistent about which souls had to undergo reincarnation: while the myths in the Republic and Phaedrus state that even the good souls had to be reincarnated, the one in Timaeus suggests that only the wicked ones were concerned.

${ }^{65}$ Procl. In Ti. 330a Diehl: Mí $\sigma \omega \tau \eta \rho i \alpha ~ \tau \tilde{\eta} \varsigma \psi v \chi \tilde{\eta} \varsigma \alpha \tilde{v} \tau \eta \pi \alpha \rho \dot{\alpha} \tau o \tilde{v} \delta \eta \mu \iota v \rho \gamma o \tilde{v} \pi \rho о \tau \varepsilon i v \varepsilon \tau \alpha \iota$

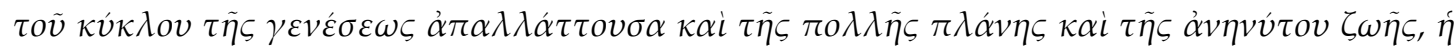

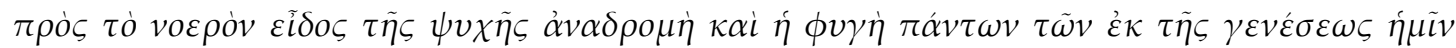

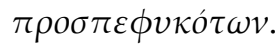


meanings, but always in relation to this world ${ }^{66}$ But even in the present instance it is still closely bound up with this life: the dangers lie in our earthly passions as much as postmortem punishments. In the same passage Proclus speaks of kathartic virtue alone

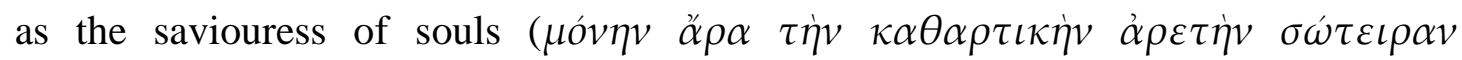
$\pi \rho \circ \sigma \rho \eta \tau \dot{\varepsilon} \sigma v \tau \tilde{\omega} v \psi v \chi \tilde{\omega} v)$, since this alone would deliver our souls from earthly desires. ${ }^{67}$ The soul's moral well-being in life is therefore intertwined with its treatment after death. If Plato adduces myths of the underworld and the associated punishments, it is primarily to serve a this-worldly purpose.

\section{Isis}

The Greeks already showed an interest in the mysteries in Egypt as early as the fifth century B.C. ${ }^{68}$ But it was not until the Hellenistic period that the cult of Isis gained prominence in Greece. Although Isis' association with mysteries is mentioned in passing in several of her aretalogies, dating from the late second century B.C. to the third century A.D., ${ }^{69}$ there is no evidence for the mysteries' presence in Greece before the Roman era. Inscriptions attesting to her mystai and orgia from various parts of the Graeco-Roman world all date to the imperial period. ${ }^{70}$ Yet none of these inscriptions reveals the hopes and beliefs of initiates, ${ }^{71}$ and none uses the words Soteira, soteria or their Latin equivalents in relation to Isis.

Our most valuable source on Isis' mysteries in Greece is Apuleius' Latin novel Metamorphoses, dated to the last decades of the second century A.D. After telling the story of Lucius' transformation into an ass and all the indignity he suffers, the last book recounts his restoration to human form thanks to Isis' intervention and his subsequent initiations into her cult. Set in the ancient town of Cenchreae east of Corinth, ${ }^{72}$ the opening scene shows Lucius contemplating his 'hope of deliverance' (11.1: spes salutis) and invoking the goddess under different names. The goddess, who declared her real name as Isis, manifested herself in his dream and told him to join the procession the following day, which would be his 'day of salvation' (11.5: dies salutaris). The goddess further promised that he would live in happiness and glory under her guardianship, and that he would continue to be favoured by her even

\footnotetext{
${ }^{66}$ See Ast (1835-8), vol. 3, 351-4; Brandwood (1976), 860; Menn (2013) (209-15 on Pl. Resp. 621c; Phd. $107 \mathrm{c}-\mathrm{d})$.

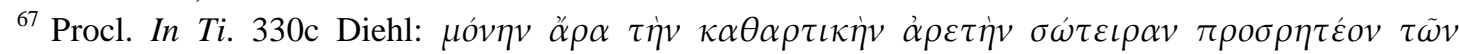

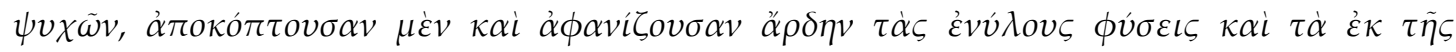

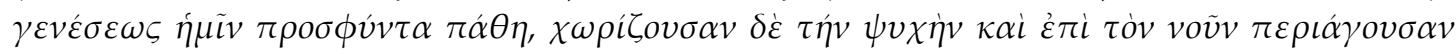

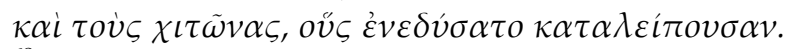

${ }^{68}$ Hdt. 2.171 .

${ }^{69}$ Isis' aretalogies: these are found in Maroneia (1ate 2ndC B.C., RICIS 114/0202), Andros (1stC B.C., RICIS 202/1801), Cyme ( $1^{\text {st }}$ C A.D.? RICIS 302/0204), Thessalonike ( $1^{\text {st }} / 2$ ndC A.D., RICIS 113/0545), Ios (3rdC A.D., RICIS 202/1101), Telmessos (late Hellenistic, RICIS 306/0201) and Kassandreia ( $2^{\text {nd }} C$ A.D., SEG LVIII 583, 'Supplément I' to RICIS in Bibliotheca Isiaca I (2008), 77-122, at 105-7, no. 113/1201). Isis' connection with mysteries is mentioned in the ones from Maroneia (lines 22-4), Andros (lines 11-12), Cyme (line 22), and Ios (line 22).

${ }^{70}$ RICIS 102/0201 (Cenchreae), 113/0552 (Thessalonike), 113/0505 (Thessalonike), 113/0537 (Thessalonike), 205/0104 (Samos), 303/1301 (Tralles), 308/0401 (Prusa), 312/0501 (Sagalassos), 501/0127 (Rome), 501/0165 (Rome), 501/0166 (Rome), 501/0185 (Rome), 501/0188 (Rome), 501/0190 (Rome), 505/0101 (Brindisi), 512/0201 (Forlimpopoli), 512/0602 (Modena).

${ }^{71}$ That is, except a funeral stele from Bithynia (RICIS 308/1201), in which the initiate tells us that he 'ran to the havens of the blessed' ( $\left.\mu \alpha \kappa \alpha \rho \omega \nu \delta^{\prime} \varepsilon \dot{\varepsilon} \delta \alpha \mu \nu v \varepsilon i \zeta \lambda \iota \mu \varepsilon \dot{\varepsilon} v \varsigma\right)$ because of his initiation.

${ }^{72}$ The hieron of Isis in Cenchreae is mentioned in Paus. 2.2.3. Its archaeological remains have been tentatively identified: Rife (2010), 402-11.
} 
after death. ${ }^{73}$ During the festival that followed, Lucius approached the priest who carried in his hand his 'destiny and salvation' (11.12: fata salutemque), that is, the garland of roses which transformed him as promised. In all three instances the noun salus and the adjective salutaris refer to his liberation from animal form and the sufferings it brought. ${ }^{74}$ The deliverance was physical rather than spiritual.

More controversial, however, is the use of salus three times by the priest who officiated at Lucius' first initiation into Isis' mysteries:

'both the gates of death and the guardianship of life (salutis tutela) were in the goddess's hands, and the act of initiation was performed in the manner of voluntary death (voluntaria mors) and salvation obtained by favour (precaria salus). In fact, those who had finished their life's span and were already standing on the very threshold of light's end, if only they could safely be trusted with the great unspoken mysteries of the cult, were frequently drawn forth by the goddess's power and in a manner reborn through her providence and set once more upon the course of renewed life (novae salutis curricula). ${ }^{75}$

Griffiths thinks that in all three occurrences salus refers to 'life in the spiritual as well as the physical sense', but emphasizes the spiritual now that physical metamorphosis is attained. Burkert, on the other hand, thinks that the 'new life' in Apuleius is 'life in this world of ours' and that the concern remained this-worldly rather than spiritual. ${ }^{76}$ The idea of 'voluntary death' and 'salvation' comes close to that of the 'dying and rising' god postulated in some early scholarship. We are reminded of the myth of Isis and Osiris, how Osiris was killed by Seth, his body dismembered, and subsequently restored to life by Isis, after which he became the lord of the underworld. Plutarch, who provides the earliest surviving narrative of the myth, notes that Isis' quest for Osiris was integrated into the initiatory rituals, ${ }^{77}$ and some scholars think that rituals imitating the fate of Osiris probably took place in underground chambers found in Isis' temples. ${ }^{78}$ Lucius speaks ambiguously of how, during his first initiation, 'I came to the boundary of death (accessi confinium mortis) and, having trodden the threshold of Proserpina, I travelled through all the elements and returned' (11.23). One common interpretation is that Lucius entered the realm of the dead, the underworld, where the body of the deceased - identified with Osiris in Egyptian tradition - would be reunited with the soul at night and be revived at dawn. On this view, initiation into Isis' mysteries corresponds to 'une sorte d'osirianisation'. ${ }^{79}$ However, even if all this

\footnotetext{
${ }^{73}$ Apu. Met. XI.6 (vives autem beatus, vives in mea tutela gloriosus).

${ }^{74}$ Deliverance from his sufferings is hinted at in 11.2 (tu saevis exanclatis casibus pausam pacemque tribue) and 11.12 (quod tot ac tantis exanclatis laboribus, tot emensis periculis, deae maximae providentia alluctantem mihi saevissime Fortunam superarem). See also 11.15, where the priest says that Lucius is 'set free from his tribulations of old' (pristinis aerumnis absolutus). Cf. Griffiths (1975), who thinks that dies salutaris (11.5) and salus (11.12) may mean 'spiritual salvation' in addition to physical deliverance.

75 Apu. Met. XI. 21 (tr. Loeb).

${ }^{76}$ Griffiths (1975), 280; one can still see in Griffiths the influence of Reitenstein (1910), 39-40. Cf. Burkert (1987), 18

${ }^{77}$ Plut. De Is. et Os. 2, 27. The myth is narrated mainly in chapters 12-20; see also Diod. Sic. 1.21-22.

${ }^{78}$ E.g. Griffiths (1975), 298-9, on Apu. Met. XI.23; Malaise (1981), 491. See also Malaise (1972), 23940 , on the temples of Isis.

${ }^{79}$ E.g. Cumont (1963), 245; Malaise (1972), 234-5; Griffiths (1975), 296-9; Malaise (1981), 486-93; Bricault (2013), 435-6 (quotation at 436). Cf. Nilsson (1967-74), vol. 2, 634: 'Er existiert kein Beleg
} 
were true, it would be re-birth into this world, as a better person, not into the afterlife. When the priest said that 'those who had finished their life's span' would be 'in some sense reborn' after initiation, he is not referring to a life beyond, a blessed afterlife which triumphs over death, but to a new stage of (this) life free from its former afflictions on earth. Apuleius nowhere alludes to the myth of Osiris. Nor is there any indication that Lucius' initiation involved the enactment of, or participation in, the god's sufferings. Any reconstruction of the initiates' experience must remain highly uncertain, as is the precise nature of Isis' mysteries in the Greek world. ${ }^{80}$

Apuleius refers to Isis as 'saviouress' (sospitatrix) three times in Book XI (11.9, 15, 25), twice before Lucius' initiation and once afterwards. None of these references appears in an eschatological context, and the last occurrence in 11.25 concerns a range of protective functions that are predominantly this-worldly. ${ }^{81}$ Although Apuleius elsewhere mentions Isis' power over Tartarus (11.25), her power to forestall death and her favour for Lucius even beyond his lifetime (11.6), the otherworldly aspect of her power is not expressed in these passages with the language of salus. Even if her mysteries had an eschatological aspect (as hinted at by these passages and made probable by Eleusinian influence), they are not exclusively or predominantly eschatological in character in Apuleius' account. Lucius, it seems, was attracted not so much by any spiritual or eschatological promise that initiation had to offer, but by the portent of wealth in his dream (11.20), and his most tangible benefit after initiation was his prosperity as a lawyer in Rome. Although Lucius' experience was considered by Nock as a 'conversion' involving marked spiritual reorientation, ${ }^{82}$ this 'conversion' did not, as Burkert notes, result in any withdrawal from this world and worldly interest, and the picture is far from dominated by spiritual or eschatological preoccupation.

\section{Meter and Attis}

Unlike the mysteries of Dionysus or Isis, there survives no detailed description of Meter's initiatory rituals in Greece after her cult arrived in the late seventh and early sixth centuries B.C. Her cult was brought from Pessinus to Rome in 204 B.C., and it is much later, in the imperial period, that information is richest about her rituals in the west, where she is known as Magna Mater. ${ }^{83}$ Usually referred to as Meter or Meter Theon in Greece, the goddess was also called Kybele, a Greek theonym taken from the Phrygian epithet kubileya (probably meaning 'of the mountain'). Meter was a late-comer in the use of the epithet Soteira. Not until the second century B.C. is she attested under this title, and only in isolated instances outside mainland Greece. ${ }^{84}$ The monumental collection of archaeological and epigraphic sources by Vermaseren, Corpus cultus Cybelae Attidisque, records sacrifices and dedications to Meter hyper soterias of oneself or a group, and in the imperial period pro salute of the emperor or,

dafür, dass dei fraglichen Riten einem lebenden Menschen appliziert wurden, um ihm die Sicherheit zu geben, dass er künftig das Schicksal des Osiris teilen sollte.' See also Plut. fr. 178 Sandbach, where the verb teleutan (to die) is compared to teleisthai (to be initiated).

${ }^{80}$ The general view is that Egypt did not have mystery cults: see Bremmer (2014), 110-11; Burkert (1987), 40; cf. Griffiths (1975), 189.

${ }^{81}$ Apu. Met. 11.25 .

${ }^{82}$ Nock (1933), 138-55.

${ }^{83}$ The literary, archaeological and epigraphic evidence is discussed in an excellent study: Roller (1999). Other studies on Meter are e.g. Vermaseren (1977); Thomas (1984); Borgeaud (1996); Lane (1996).

${ }^{84}$ There are only four attestations to my knowledge: SEG XXIII 687; CIG $4695=C C C A \mathrm{~V}$ no. 4;

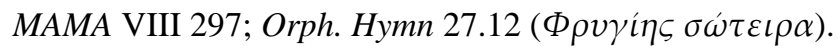


less often, oneself, ${ }^{85}$ but nothing suggests that soteria and salus mean anything other than safety and well-being in these contexts. Where literary and epigraphic sources testify to Meter's power to save, all references relate to dangers in this life. ${ }^{86}$ Our sources reveal little or nothing about the benefits hoped for by Meter's initiates, and the eschatological aspect of her cult (if any) is neither prominent nor certain at least as far as her cult in Greece is concerned. ${ }^{87}$

From the middle of the fourth century B.C., the cult of Meter came to be associated with her youthful lover Attis. ${ }^{88}$ Their relationship is recounted in different versions of the myth by Greek and Latin authors, but the most memorable elements concern his tragic death after his self-castration, when he was unable to remain faithful to Meter. ${ }^{89}$ Some historians see in Attis' vicissitudes the model of the dyingrising god, ${ }^{90}$ but in the myth preserved by Arnobius of Sicca, Jupiter explicitly denies the request that Attis be brought back to life. All that is granted is that his body would be preserved intact, his little finger could move, and his hair would grow. Far from being revived from death, he is allowed very limited survival.

A passage in Firmicus Maternus in the fourth century A.D. is frequently cited to support the view that ancient mystery cults offered eschatological soteria, and the cult is sometimes identified as that of Meter and Attis. In the course of explaining the passwords used by pagans, the Christian apologist describes a scene in the celebration of a mystery, which involves worshippers lamenting over a statue lying on a bier at night. A light is then brought in and a priest anoints the throats of all who are mourning, whispering in a low voice:

\section{$\theta \alpha \rho \rho \varepsilon \tilde{\imath} \tau \varepsilon \mu \hat{v} \sigma \tau \alpha \iota \tau o \tilde{v} \theta \varepsilon o \tilde{v} \sigma \varepsilon \sigma \omega \sigma \mu \varepsilon \dot{v} o v \cdot$

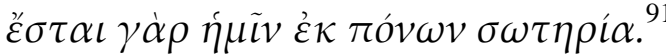 \\ 'Take heart, initiates, the god has been saved! \\ There will be salvation from sufferings for us.'}

Firmicus does not say to which mystery cult this symbolon belongs, and the god thus 'saved' has been disputed since the early $20^{\text {th }}$ century: is it Attis, Osiris or some other $\operatorname{god} ?^{92}$ As we have seen, Attis was never brought back to life; and Isis' mysteries in

\footnotetext{
${ }^{85}$ Hyper soterias: $C C C A$ I nos. 115,121 , VI 436; to which add SEG VI 718; pro salute: e.g. CCCA III nos. 401, 405, 406, 407, 417, 464, IV 172, 219, V 79-80, 87, and many more.

${ }^{86}$ Hdt. 4.76 (Anacharsis returned to Scythia 'safe and sound' $\sigma \tilde{\omega} \varsigma \kappa \alpha i \dot{v} \gamma \iota \eta \bar{\zeta}$ ); Diod. Sic. 3.55 .8 (the Amazon Myrina invokes Meter Theon hyper soterias during a storm at sea); Syll. ${ }^{3} 763$ (Meter revealed to her gallos that his companion would be $\sigma \omega \theta \dot{\eta} \sigma \varepsilon \tau \alpha \iota \dot{\varepsilon} \kappa[\tau \tilde{\omega} v] \mu \varepsilon[\gamma \alpha \dot{\alpha} \lambda \omega] \nu[\kappa \iota] v \delta \dot{v} v \omega v$, referring to his captivity while on campaign).

${ }^{87}$ Sfameni Gasparro (1985), esp. ch. 5; more concisely in Sfameni Gasparro (1982). Cf. Vermaseren (1977), 55-7, 113-23; Turcan (1989), 73-4, who, on the basis of Julian, Sallustius and Dasmicius, argues that Cybele and Attis promised the triumph of souls over death.

${ }^{88}$ On Attis, see Vermaseren (1966); Lancellotti (2002).

${ }^{89}$ The main sources are Diod. Sic. 3.58-9; Ov. Fast. 4.221-44; Paus. 7.17.9-12; Arn. Adv. Nat. 5.5-7; Serv. Comm. ad Aen. 9.115. A succinct discussion of the myth and its sources is Roller (1999), ch. 8 (n. 12 lists many other sources on the myth).

${ }^{90}$ E.g. Sfameni Gasparro (1985), esp. 30, 43-9, though distancing herself from Frazer, emphasizes throughout Attis' connection with agricultural fertility and sees in him the life and death of vegetation.

${ }^{91}$ Firm. Mat. Err. prof. rel. 22.1. Cf. Lambrechts (1962), with French summary at 61-74, who argues against the interpretation of Attis as a vegetation god and that he could offer hopes of immortality.

${ }^{92}$ The passage is sometimes linked to Attis on the basis of Firm. Mat. Err. prof. rel. 3, where Firmicus refers to the resurrection of Attis, and a passage in Damascius which links Attis to soteria from Hades
} 
Greece cannot be securely shown to have involved the ritual lament and revival of Osiris. None of the gods of mystery cults we have examined is said to have been 'saved' in the sources, nor is there secure evidence that initiates shared, or expected to share, a similar fate as that of the god. Although the word róvo is used in relation to

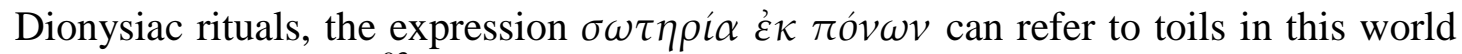
as much as the next. ${ }^{93}$ Historians have repeatedly looked for comparable rites and similar uses of $\theta \alpha \rho \rho \varepsilon \tilde{\imath} v$ in ancient mysteries; yet what is striking about this passage is not the extent to which it supposedly represents any of the ancient mysteries, but its close resemblance to Christianity. It is possible that a pagan cult was borrowing Christian language at this date. Alternatively, might Firmicus have been attributing the motif of Christ's death and resurrection and the Christian notion of soteria to some pagan cult in an attempt to illustrate paganism's perverse imitation (imitatio corrupta) of the true religion? He goes on to condemn its supposed salvation as a false promise. In any case, written in the fourth century A.D. and from a stance that is clearly hostile, this Christian text cannot be safely used to reconstruct pagan cult practice in Firmicus' own days, and still less, the earlier periods.

Firmicus' passage is sometimes associated with Attis on the basis of another late piece of evidence, which seems to link Attis with 'soteria from death'. In his biography of Isidore in the early sixth century A.D., the Greek philosopher Damascius recounts his descent into a pit in Hierapolis in Phrygia, which emitted deadly fumes and from which no one was supposed to emerge alive except the initiated. After their successful return, he dreamt that he was Attis and that the festival called Hilaria was celebrated for him by the Mother of the Gods, which (to his mind) signified their

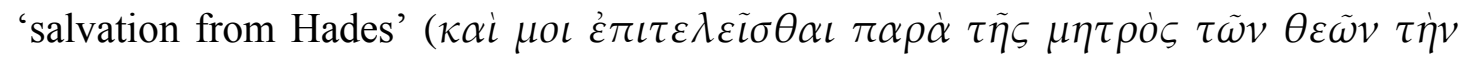

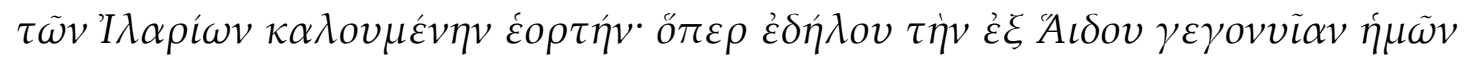
$\sigma \omega \tau \eta \rho i \alpha v) .{ }^{94}$ Attested in Rome from the fourth century A.D., the Hilaria formed part of the cycle of March festivals in honour of Magna Mater and was held after the days of ritual lamentations. This passage has been adduced as evidence that the Hilaria celebrated the 'resurrection' of Attis or his 'survival after death'. Sfameni Gasparro takes this as is 'the only explicit attestation of a soteriological prospect in an eschatological sense in the cult of Cybele', and goes on to postulate that, from a certain period onwards, participation in the March festivals would offer participants the guarantee of eschatological soteria based on the model of Attis. ${ }^{95}$ However,

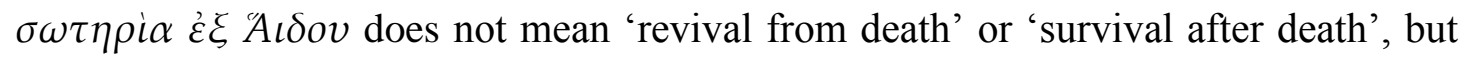
'protection from death', namely the life-threatening fumes from the pit. This passage cannot be taken as evidence that the cult could provide soteria in the sense of eschatological salvation. ${ }^{96}$

(see below). Attis: Hepding (1903), 166-8, 197 (with reservation); Frazer (1911-15), vol. 5, 272 n. 6; Dowden (2011), 296. Osiris: Loisy (1914), 104; Lagrange (1919), 448-9; Cumont (1929), 226 n. 46; Nilsson (1967-74), $3^{\text {rd }}$ ed. vol. 2, 639; Vermaseren (1977), 116; and especially Podemann Sørensen (1989), who shows that all elements in Firmicus' passage can be identified as Egyptian rites, but note his reservations at 85. Eleusis: Joly (1955). More scholarship before 1982 is collected in the commentary by R. Turcan in the Belles Lettres edition p. 313-15, who considers Osiris as the most probable candidate.

${ }^{93}$ Even when used in relation to Dionysus Lysios in Pl. Phaedrus 244d and OF 350, Tóvo refer to sufferings both in this life and in the next.

${ }^{94}$ Dam. Isid. fr. 131 Zintzen = Athanassiadi (1999), fr. 87 A.

${ }^{95}$ Sfameni Gasparro (1982), 476; Sfameni Gasparro (1985), 62-3, 85.

${ }^{96}$ North (2013), 292, warns against using this passage as evidence of actual pagan practice. 


\section{Concluding observations}

Despite the eschatological element in many of the mystery cults under discussion, what is striking is the near-absence of the language of soteria for referring to a blessed afterlife. Where post-mortem benefit is referred to, the language differs among the sources and varies from one cult to another, so that there is no consistent language with which to express the idea. Thus the Eleusinian initiates were 'blessed'

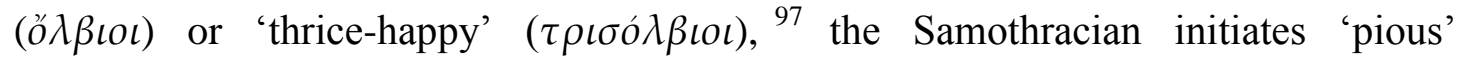
$(\varepsilon \dot{v} \sigma \varepsilon \beta \varepsilon \tilde{\iota} \varsigma),{ }^{98}$ the Dionysiac initiates 'pure' ( $\kappa \alpha \theta \alpha \rho o$ ') and granted 'release' $(\lambda \dot{v} \sigma \iota \varsigma)$ by Dionysus. ${ }^{99}$ Unlike in early Christianity, ancient Greek seems to lack a specific abstract noun to denote postmortem felicity in the Classical and Hellenistic periods, even if the idea already then existed.

Where soteria and sozein are used in connection with the gods of mysteries, there is no clear evidence that they mean anything other than protection in the hereand-now. This can be deliverance from specific dangers (such as seafaring for Samothracian initiates) or more general protection from potential, non-specific, threats. The only exception is Plato's use of soteria in his Phaedo, ${ }^{100}$ where he transposes the word from its normal application in the realm of earthly dangers to dangers awaiting the unjust in the underworld. But the dominant language in Plato remains that of purification ( $\kappa \alpha \dot{\alpha} \theta \alpha \rho \sigma i \varsigma)$ when expressing the soul's freed status from bodily contamination in this life and, by virtue of that, from post-mortem punishment. The philosopher's isolated use of soteria is not representative of how other Greeks of his time would normally understand the concept, nor is it representative of the other uses of soteria (and its cognates) in his work, which remain this-worldly. ${ }^{101}$

The claim that the gods of ancient mystery cults were often called Soter cannot be sustained. As we have seen, never were Demeter and Kore attested as Soteira in the Eleusinian mysteries; ${ }^{102}$ the Samothracian gods were rarely called Soteres and only by virtue of their association with the Dioscuri; ${ }^{103}$ Dionysus released his initiates from ancestral guilt in his capacity as Lysios, not Soter; and Isis is hardly attested as Soteira in the context of her mysteries. ${ }^{104}$ Mysteries of Kore Soteira are attested in Cyzicus in the imperial period, but Kore already bore this epithet on the city's fourth-century coins as its patron goddess, and it does not seem to denote specifically the benefits of her mysteries, about which we know little. ${ }^{105}$ Some gods of mysteries even remain nameless: the Samothracian initiates apparently did not

\footnotetext{
${ }^{97}$ Pind. fr. 131, 137; Soph. fr. 837.

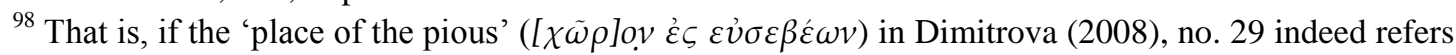
to privileged treatment after death.

${ }^{99}$ Graf and Johnston (2013), nos. 5-7, 9, 26; OF 350.

${ }^{100} \mathrm{Pl}$. Phd. $107 \mathrm{c}-\mathrm{d}$.

101 See n. 63.

${ }^{102}$ Andrich (1894), 47-51.

${ }^{103}$ Orph. Hymn 38.

${ }^{104}$ Isis is sospitatrix in Apu. Met. 11.9, 15, 25, but the first two instances have no connection to mysteries, and the last used in a predominantly this-worldly sense.

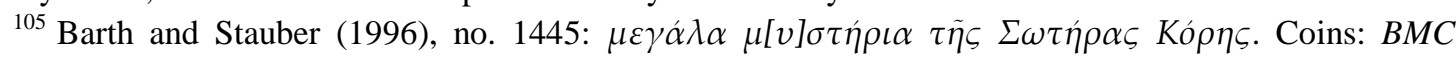
Mysia p. 36, nos. 124-33; SNG Copenhagen, Mysia nos. 53-6, 58-62; SNG von Aulock, Mysien nos. 1217-26.
} 
know, ${ }^{106}$ and did not need to know, the gods' name and identity for their 'saving' power to be effective.

If the gods of mysteries could affect the soteria of the people, it was soteria in an earthly sense. It is outside the mysteries, in the everyday worship of these gods by initiates and non-initiates alike in relation to earthly concerns, that the concept of soteria and the epithet Soter/Soteira are most common. Worshippers could pray or sacrifice to the gods of mysteries, as they could to any other gods, for soteria. Several Attic inscriptions, for instance, attest to sacrifice to the Eleusinian goddesses, performed 'for health and safety' ( $\left.\dot{\phi} \phi^{\prime} \dot{v} \gamma \iota \varepsilon \dot{\varepsilon} \alpha \iota \alpha \dot{i} \sigma \omega \tau \eta \rho i \alpha \iota\right)$ of the Athenians by the epimeletai of the Mysteries or other officials of Eleusis. ${ }^{107}$ Individuals might set up dedications to the gods in hope and gratitude for soteria. In central Thrace, two altars (undated) were set up by the priest of Dionysus to the god, one for the soteria of himself and his children who were initiated with him, and another for his children and 'his initiates, whom, blessed Dionysus, save $(\sigma \tilde{\omega} \zeta \varepsilon)$ ' ${ }^{108}$ A third altar, from Dorylaion in Phrygia in the imperial period, was dedicated to Dionysus for the soteria of the dedicator himself and someone called Bakchos, possibly a 'cult title of one of the officials of his local Bacchic organizations' according to Cole. ${ }^{109}$ Such sacrifices and dedications could be offered to all the gods, and not just the gods of mystery cults. In none of these cases does soteria or its cognate carry any hint of anticipation of postmortem benefits. These prayer formulae and dedicatory inscriptions reveal nothing about the worshippers' otherworldly beliefs. Sacrifices and dedications for the soteria of oneself and others is a common religious practice throughout Greek antiquity. They completely accord with religious convention, and in sacrificial and dedicatory contexts the word soteria usually means the general 'well-being' and physical 'protection' of the beneficiaries named before the god. There is no reason to assume that the soteria in these texts relates to protection after death.

If the soteria offered by these cults was primarily this-worldly, we can nevertheless still ask how different (if at all) the soteria experienced by initiates was compared to the soteria they could obtain by other ritual means. How long-lasting and life-changing was the soteria offered by Greek mysteries? Protection thus obtained, it may be hoped, would be more permanent and effective than that attained via other cult practices; nevertheless this is not actually borne out in the evidence. Apuleius shows that Lucius entered into a more intense relation with and personal devotion to Isis, but not how effectively he was immune from disasters in this life and/or the next. Individuals could be initiated into more than one mystery cult and, in some cases, more than once, ${ }^{110}$ and it was not considered problematic in Greek polytheism to try again or to try out several options at the same time. But even if mysteries might ward off life-threatening dangers or afflictions after death, none of them could ward off

\footnotetext{
${ }^{106}$ Bowden (2010), 49.

${ }^{107}$ IG II $^{2} 661$ (= II ${ }^{3}$ 915, I.Eleusis 181), 807 (= II ${ }^{3} 1188$, I.Eleusis 202), 949 (= I.Eleusis 229), 992 (II $^{3}$ 1372). See also $I G \mathrm{II}^{2} 1304$ (= I.Eleusis 211). On the normal duties of the epimeletai, see Clinton's commentary on I.Eleusis 208: these include, inter alia, supervising the sacrifice at the Great Mysteries and conducting sacrifice at the Lesser Mysteries.

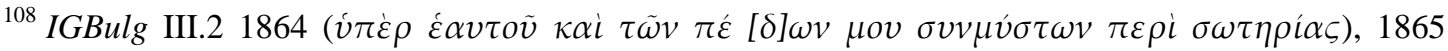
( $\mu v \sigma \tau \tilde{\omega} v i \delta i \omega v$, ov $\varsigma \sigma \tilde{\omega} \zeta \varepsilon, \mu \alpha \dot{\alpha} \kappa \alpha \rho \Delta \iota \dot{v} v \sigma \varepsilon)$.

${ }^{109}$ S.C. Cole (1991), 'Dionysiac Mysteries in Phrygia in the Imperial Period', EA 17, 41-9, plate 5, quotation at 45 .

${ }^{110}$ But initiation into some mysteries, such as the epopteia at Eleusis, could be conducted only once.
} 
death itself. As the disillusioned parents of their dead seven-year-old son wrote on his epitaph, despite the mysteries, 'no one is able to unwind the thread of the Fates'. ${ }^{111}$

The character of soteria, then, is remarkably consistent from its emergence in the late Archaic period down to about the fourth century A.D. ${ }^{112}$ Not even in mystery cults did it acquire an eschatological sense, except in a handful of cases from the Roman period where Christian influence on the concept seems plausible. But such instances come from much later, and in one case Christian, sources, and even here the eschatological dimension is not entirely certain. The salus offered by Isis' mysteries in Greece, as we have seen, appears to have been predominantly if not exclusively this-worldly. The ambiguous sense of salus in Apuleius' Metamorphoses 11.21 exemplifies the concept's possible fuzzy edges between this world and the next in the later period. There is perhaps no need to press for a precise meaning when it was probably intended to be unclear. The priest might have been speaking ambiguously to allow initiates (and readers) to interpret salus as they wish. It is also questionable to what extent there was ever an 'official' doctrine about Isis' mysteries in Greece, and whether there was ever any agreed understanding of what the mysteries promised. Rather different is Firmicus' use of soteria in a supposedly other-worldly sense in relation to some pagan cult: it might reflect pagan borrowing of Christian language at that date, or it might have been influenced by the author's own interpretation of the Greek concept - an interpretation or reinterpretation which is not supported by the rest of the sources, but which is probably affected by the ideological and political contexts of his time. An other-worldly emphasis of soteria, if indeed present in the cult of Meter or some other pagan cult, might well be a late adaptation or distortion in a context of religious competition. ${ }^{113}$ If some later authors succeeded in ascribing to soterialsalus an eschatological stance that was alien to it in earlier periods, this only shows the malleability of the concept. It is the very imprecision of the concept that allowed its meaning to be adapted in this way.

When Burkert emphasized the worldly character of ancient mysteries, his argument was based on the general nature and promise of these cults rather than the language they used. Our present analysis confirms Burkert's main contentions from a linguistic perspective: ancient mystery cults were not 'Erlösungsreligionen' whether in the nature of their promises or in the language used of these rites. Although Burkert has been criticized for downplaying the spiritual and otherworldly aspect of mysteries, ${ }^{114}$ one of his most valuable insights must stand: that concentration on their eschatological aspects may obscure more practical concerns in this world. Even if there was an eschatological component, it becomes clear from reviewing the sources that this was never the exclusive concern of ancient mysteries; their character was still very different from Christianity, which is explicitly and predominantly concerned with the destiny of the soul.

\footnotetext{
${ }^{111}$ IG XIV 1449; IGUR 1169; Jaccottet (2003), vol. 2, no. 195 (third to fourth century A.D.). The

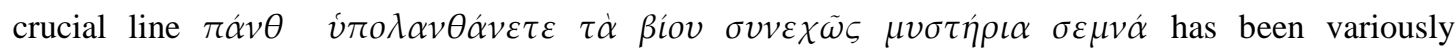
interpreted; see Burkert (1987), 28-9, who translates 'forget all the august mysteries of life, one after the other'. See also the epitaphs of other children who died young despite initiations into the Dinysiac and other mysteries, collected under Harland (2014), no. 100.

${ }^{112}$ I am preparing a study of 'saviour' gods and the concept of soteria in ancient Greece.

${ }^{113}$ Lancellotti (2002) demonstrates how traditions of Attis might have been adapted and reinterpreted over time by different circles.

${ }^{114}$ E.g. Brenk (1989); Bianchi (1995), 1-5.
} 
In their attempt to demonstrate pagan influence on early Christianity, scholars in the late nineteenth and early twentieth centuries were far more interested in linguistic and ritual parallels between the two cultures than in their differences. They have inevitably overlooked the important fact that soteria was used by the Greeks even in the context of ancient mysteries - in a this-worldly sense. Soteria for the Greeks did not have the eschatological connotation that the English word 'salvation' has for us today. If early Christianity indeed derived its most important concept from Greek religion, it was a derivation with a significant adaptation and change in meaning.

\section{Bibliography}

Angus, S. (1925), The Mystery-Religions and Christianity (London).

Anrich, G. (1894), Das antike Mysterienwesen in seinem Einfluss auf das Christentum (Göttingen).

Ast, F. (1835-8), Lexicon Platonicum (Leipzig).

Athanassiadi, P. (1999), Damascius: The Philosophical History (Athens).

Barth, M. and Stauber, J. (eds) (1996), Inschriften Mysia \& Troas (Munich).

Bernabé, A. (2002), 'La toile de Pénélope: a-t-il existé un mythe orphique sur Dionysos et les Titans?', Revue de l'histoire des religions 219, 401-33.

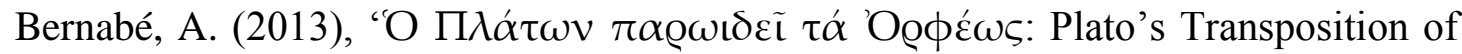
Orphic Netherworld Imagery' in V. Adluri (ed.), Philosophy and Salvation in Greek Religion (Berlin), 117-49.

Bernabé, A. and Jiménez San Cristóbal, A.I. (2008), Instructions for the Netherworld (Leiden).

Bianchi, U. (ed.) (1979), Mysteria Mithrae (Leiden).

Bianchi, U. (1995), 'Walter Burkert: Antike Mysterien', Gnomon 67, 1-5.

Borgeaud, P. (1996), La mère des dieux (Paris).

Brandwood, L. (1976), A Word Index to Plato (Leeds).

Bremmer, J.N. (2014), Initiation into the Mystereis of the Ancient World (Berlin).

Brenk, F. (1989), 'Walter Burkert: Anicent Mystery Cults', Gnomon 61, $289-92$.

Bricault, L. (2013), Les cultes Isiaques dans le monde Gréco-Romain (Paris).

Burkert, W. (1983), Homo Necans (Berkeley).

Chantraine, P. (1933), La formation des noms in grec ancien (Paris).

Chantraine, P. (1968-80), Dictionnaire étymologique de la langue grecque (Paris).

Clauss, M. (1990), Mithras: Kult und Mysterien (Munich).

Clinton, K. (1992), Myth and Cult: the Iconography of the Eleusinian Mysteries (Stockholm).

Clinton, K. (2001), 'Initiates in the Samothracian mysteries, September 4, 100 B.C.', Chiron 31, 27-35.

Clinton, K. (2003), 'Stages of Initiation in the Eleusinian and Samothracian Mysteries', in M.B. Cosmopolous, Greek Mysteries (London), 50-78.

Clinton, K. (forthcoming), Samothrace 12: The Religion of the Great Gods (London).

Cole, S.G. (1984), Theoi Megaloi (Leiden).

Cole, S.G. (2007), 'Finding Dionysus', in D. Ogden (ed.), A Companion to Greek Religion (Malden), 327-41.

Cosmopoulos, M.B. (ed.) (2003), Greek Mysteries (London).

Cumont, F. (1963), Les religions orientales dans le paganisme romain (Paris), 4th ed.

Dimitrova, N.M. (2008), Theoroi and Initiates in Samothrace (Princeton, New Jersey). Dodds, E.R. (1951), The Greeks and the Irrational (Berkeley). 
Dodds, E.R. (1960), Euripides: Bacchae (Oxford), $2^{\text {nd }}$ ed.

Dowden, K. (2011), 'The Myth that Saves: Mysteries and Mysteriosophies', in K.

Dowden and N. Livingstone (eds), A Companion to Greek Mythology

(Chichester), 283-300.

Edmonds III, R.G. (2003), Myths of the Underworld Journey (Cambridge).

Edmonds III, R.G. (2013), Redefining Ancient Orphism (Cambridge).

Frazer, J.G. (1911-15), The Golden Bough, 12 vols (London), $3^{\text {rd }}$ ed.

Friedrich, R. (2000), 'Dionysos among the Dons: the New Ritualism in Richard Seaford's Commentary on the Bacchae', Arion 7, 115-52.

Gardner, P. (1911), The Religious Experience of St. Paul (London).

Gardner, P. (1919), 'Mysteries (Greek, Phrygian etc.)' in J. Hastings, Encyclopaedia of Religion and Ethics (Edinburgh), vol. 9, 81.

Graf, F. (1974), Eleusis und die orphische Dichtung (Berlin, New York).

Graf, F. (1993), 'Dionysian and Orphic Eschatology', in T.H. Carpenter and C.A. Faraone (eds), Masks of Dionysus (Ithaca, London), 239-58.

Graf, F. (2003), 'Lesser Mysteries - Not Less Mysterious', in Cosmopoulos (2003), 241-62.

Graf, F. (2010), “The Blessings of Madness": Dionysos, Madness, and Scholarship', $A R G 12,167-80$.

Graf, F. and Johnston, S.I. (2013), Ritual Texts for the Afterlife (London, New York), $2^{\text {nd }}$ ed.

Graf, F (2017). 'Theoi Soteres', $A R G$

Griffiths, J.G. (1975), Apuleius: The Isis-Book (Metamorphoses, Book XI) (Leiden).

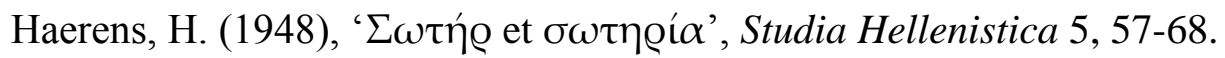

Halliday, W.R. (1925), The Pagan Background of Early Christianity (Liverpool; London).

Harland, P.A. (2014), Greco-Roman Associations II (Berlin).

Hasluck, W. (1910), Cyzicus (Cambridge).

Hemberg, B. (1950), Die Kabiren (Uppsala).

Hepding, H. (1903), Attis: sine Mythen und sein Kult (Giessen).

Hinnells, J.R. (1994), Studies in Mithraism (Rome).

Hordern, J. (2000), 'Notes on the Orphic Papyrus from Gurôb', ZPE 129, 131-40.

Jaccottet, A.F. (2003), Choisir Dionysos (Lausanne).

Jim, T.S.F. (2015), 'Can Soteira be Named? The Problem of the Bare Trans-divine Epithet', ZPE 195 (2015), 63-74.

Johnston, S.I. and T.M. McNiven (1995), 'Dionysos and the Underworld in Toledo', MusHelv 53, 25-36.

Johnston, S.I. (1999), Restless Dead (Berkeley, London).

Johnston, S.I. (2004), 'Mysteries', in S.I. Johnston (ed.), Religions of the Ancient World (Cambridge, Mass; London), 98-111.

Joly, R. (1955), 'L' exhortation au courage ( $\theta \alpha \varrho \varrho \varepsilon \tilde{\imath} v)$ dans les mystères', REG 68, 164-70.

Karadima-Matsa, C. and Dimitrova, N. (2003), 'Epitaph for an Initiate at Samothrace and Eleusis', Chiron 33, 335-45.

Kearns, E. (1990), 'Saving the City', in O. Murray and S. Price (eds.), The Greek City from Homer to Alexander (Oxford), 323-44.

Kirk, G.S. (1979), The Bacchae of Euripides (Cambridge),

Lancellotti, M.G. (2002), Attis: Between Myth and History (Leiden).

Lagrange, M.J. (1919), 'Mélange I. Attis et le christianisme', RBibl 28, 419-80. 
Lagrange, M.J. (1937), Introduction a l'étude du Nouveau Testament. Critique Historique I, Les Mystères, L'Orphisme (Paris).

Lambrechts, P. (1962), Attis, van herdersknaap tot god (Brussels),

Lane, E.N. (1996), Cybele, Attis and Related Cults (Leiden).

Lewis, N. (1959), Samothrace: The Ancient Literary Sources (London).

Loisy, A. (1914), Les mystères païens et le mystère chrétien (Paris).

Macchioro, V. (1930), From Orpheus to Paul: A History of Orphism (London).

Malaise, M. (1972), Les conditions de pénétration et de diffusion des cultes égyptiens en Italie (Leiden).

Malaise, M. (1981), 'Contenu et effects de l'initiation isiaque', AntCl 50, 483-98.

Menn, S. (2013), 'Plato's Soteriology?' in V. Adluri (ed.), Philosophy and Salvation in Greek Religion (Berlin), 191-216

Mylonas, G.E. (1961), Eleusis and the Eleusinian Mysteries (Princeton).

Nilsson, M.P. (1967-74), Geschichte der griechischen Religion (Munich), $3^{\text {rd }}$ ed.

Nock, A.D. (1933), Conversion (Oxford).

North, J. (2013), 'Power and its redefinitions: the vicissitudes of Attis', in L. Bricault and C. Bonnet (eds), Panthée: Religious Tranformations in the Graeco-Roman Empire (Beiden), 279-92.

Parker, R. (1983), Miasma (Oxford).

Parker, R. (2005), Polytheism and Society at Athens (Oxford).

Parker, R. (2011), On Greek Religion (Cornell).

Podemann Sørensen, J. (1989), 'Attis or Osiris? Firmicus Maternus, De errore 22', in J. Podemann Sørensen (ed.), Rethinking Religion: Studies in the Hellenistic Process (Copenhagen), 73-86.

Polinskaya, I. (2013), A Local History of Greek Polytheism (Leiden).

Reitzenstein, R. (1910), Die hellenistiscen Mysterien-religionen (Leipzig).

Richardson, N.J. (1974), The Homeric Hymn to Demeter (Oxford).

Rife, J.L. (2010), 'Religion and Society at Roman Kenchreai', in S.J. Friesen, D.N. Schowalter and J.C. Walters (eds), Corinth in Context (Leiden), 391-432.

Robert, L. (1978), 'Documents d'Asie Mineure', BCH 102, 395-543 (reprinted in Documents d'Asie Mineure [1987], 91-239).

Roller, L.E. (1999), In Search of God the Mother (Berkeley, London).

Rose, H.J. (1936), 'The Ancient Grief: A Study of Pindar, Fr. 133 (Bergk)”, in C. Bailey (ed.), Greek Poetry and Life (Oxford), 79-96.

Rose, H.J. (1943), 'The Grief of Persephone', HThR 36, 247-50.

Roux, J. (1970-2), Euripide: les Baccantes (Paris).

Sandy, J.E. (1900), The Bacchae of Euripides (Cambridge).

Schachter, A. (1981-94), Cults of Boeotia (London).

Schachter, A. (2003), 'Evolution of a Mystery Cult: the Theban Kabiroi', in M.B. Cosmopoulos (ed.) (2003), Greek Mysteries (London), 112-42.

Schwyzer, E. (1934-71), Griechische Grammatik (Munich).

Seaford, R. (1981), 'Dionysiac Drama and the Dionysiac Mysteries', CQ 31, 252-75.

Seaford, R. (1994), 'Sophocles and the Mysteries', Hermes 122, 275-88.

Seaford, R. (1996), Euripides: Bacchae (Warminister).

Sfameni Gasparro, G. (1982), 'Sotériologie et aspects mystiques dans le culte de Cybèle et d'Attis', in U. Bianchi and M.J. Vermaseren (eds.), La soteriologia dei culti orientali nell'Impero roman (Leiden), 472-9.

Sfameni Gasparro, G. (1985), Soteriology and Mystic Aspects in the Cult of Cybele and Attis (Leiden). 
Smith, J.Z. (1990), Drudgery Divine: On the Comparison of Early Christianities and the Religions of Late Antiquity (Chicago).

Sourvinou-Inwood, C. (1997), 'Reconstructing change: ideology and the Eleusinian Mysteries', in M. Golden and P. Toohey (eds), Inventing Ancient Culture (London), 132-64.

Sourvinou-Inwood, S. (2003), 'Festival and mysteries: aspects of the Eleusinian cult', in M.B. Cosmopoulos (ed.), Greek Mysteries (London, New York), 25-49.

Tarn, W. (1952), Hellenistic Civilization (London), $3^{\text {rd }} \mathrm{ed}$.

Thomas, G. (1984), 'Magna Mater and Attis', ANRW II 17.3, 1500-35.

Turcan, R. (1982), 'Salut mithriaque et sotériologie néoplatonicienne', in U. Bianchi and M.J. Vermaseren (eds.), La soteriologia dei culti orientali nell'Impero roman (Leiden), 173-89.

Turcan, R. (1989), Les cultes orientaux dand le monde Romain (Paris).

Vanderlip, V.F. (1972), The Four Greek Hymns of Isidorus and the Cult of Isis (Toronto).

Vermaseren, M.J. (1966), The Legend of Attis in Greek and Roman Art (Leiden).

Vermaseren, M.J. (1977), Cybele and Attis (London).

Versnel, H.S. (1990), Inconsistencies in Greek and Roman Religion I. Ter Unus (Leiden).

Ward, S.W. (2013), Penology and Echatology in Plato's Myths (Bloomington), $2^{\text {nd }}$ ed.

West, M.L. (1983), The Orphic Poems (Oxford).

Willoughby, H.R. (1929), Pagan Regeneration: A Study of Mystery Initiations in the Greco-Roman World (Chicago).

Wobbermin, G. (1896), Religionsgeschichtliche Studien zur Frage der Beeinflussung des Urchristentums durch das antike Mysterienwesen (Berlin). 